\title{
17
}

\section{Houses in and out of the Swamp}

\author{
Jack Golson
}

In the 1930s, the settlement pattern of the upper Wahgi Valley was one of scattered homesteads. Our information comes from areas above the valley floor, so there is no mention of any swampland dwellings. According to Georg F. Vicedom, who in 1934 established the Lutheran Mission at Ogelbeng on what Russell Blong (1986: 288) calls the southeastern apron of the Mt Hagen volcano, homesteads were loosely grouped in settlements sharing the same name, which could contain from three to over 20 dwelling houses and averaged around eight to 10 (Vicedom and Tischner 1943-48: 143-145, 147, 156; 1983: 161, 165, 175). The focus of such settlements was a ceremonial ground established by a clan leader, who had his men's house there. The other houses of the settlement were built at varying distances. They consisted of the men's houses of other polygamous males of the clan, separate women's houses for each of their wives and her children, and family houses where monogamous couples lived with their offspring.

\section{Houses at Kuk Swamp}

\section{Distribution and location}

Traditionally, houses had some form of shallow ditch dug close to the wall to collect water from the eaves and channel it away, the spoil from its digging being piled against the wall (Vicedom and Tischner 1943-48: 163; 1983: 183). At Kuk, we discovered that in the past houses had also been built in the swamp, with ditches sometimes close to a metre deep to act as sumps. The material dug from the ditch was used to raise the floor above the level of the swamp and sometimes the underlying grey clay of the swamp stratigraphy came to form the floor itself (Fig. 17.1). The practice meant that house sites appeared as mounds in the swamp (Fig. 17.2). Most of the sites shown in Figure 17.3 were recognised because of this.

Most house sites were discovered in 1972, the first year of the Kuk project, when the dry season was long and very dry and major drainage was done in the eastern half of the Research Station (cf. Fig. 17.3 and Golson 1976: Fig. 3, which maps the house sites discovered in 1972). In the course of draining block A9, where our work started, we noticed that water from the last rains of the season was collecting in linear surface hollows across the corridors that our workmen had cleared through the thick swampgrass cover in preparation for the digging of north-south drains at $22.5 \mathrm{~m}$ intervals. We soon realised that these surface hollows marked the drainage lines of former field systems visible on the aerial photographs that we used to plan our archaeological strategy. We put our workmen to clearing, by bushknife, the whole of block A9. This exposed not only field systems and the major disposal channels that served them, but also, in the northeast corner of the block, the first house mounds. 


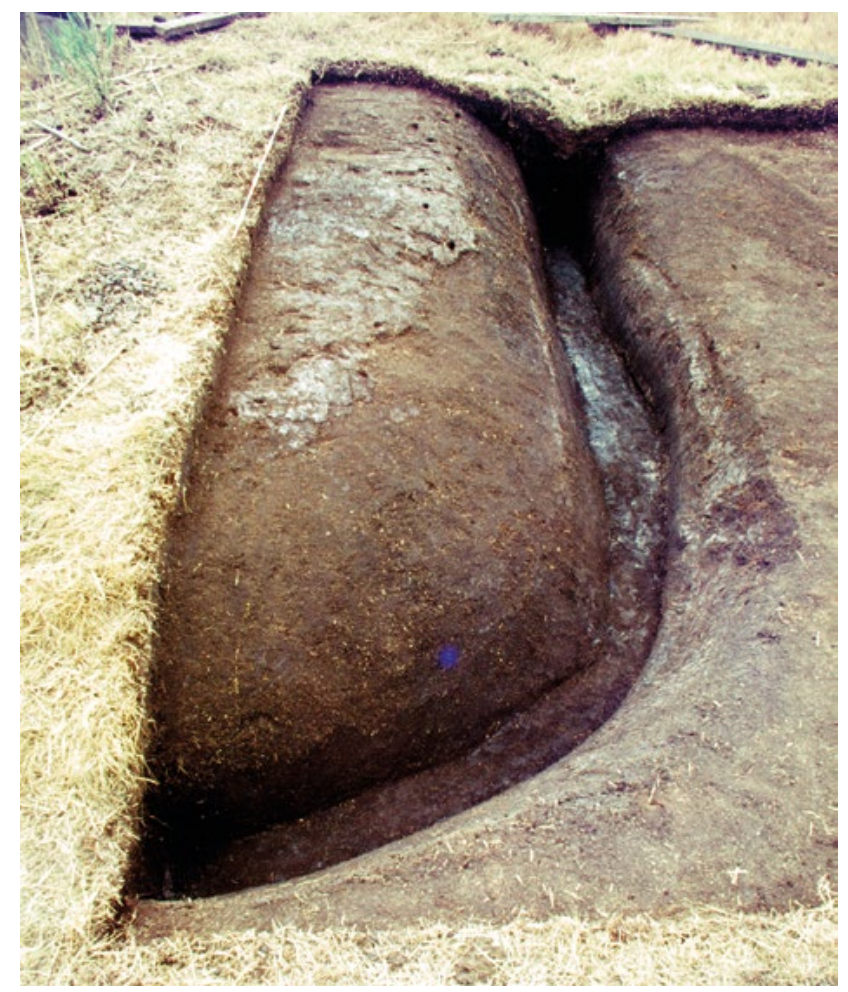

Figure 17.1 Looking east over House B at an early stage of excavation.

The earth from the house ditch raised the level of the floor, making the site visible at the surface when the swamp grass was removed (cf. Fig. 17.2). The grey clay through which the ditch was dug served to make the floor itself. The plan of the house after excavation is shown in Figure 17.5 and its location in Figure 17.3 Inset 1a. The ranging pole lying along the north edge of the excavation is graduated at $200 \mathrm{~mm}$ intervals.

Source: Photograph by Ron Lampert, Kuk archive, 1972.

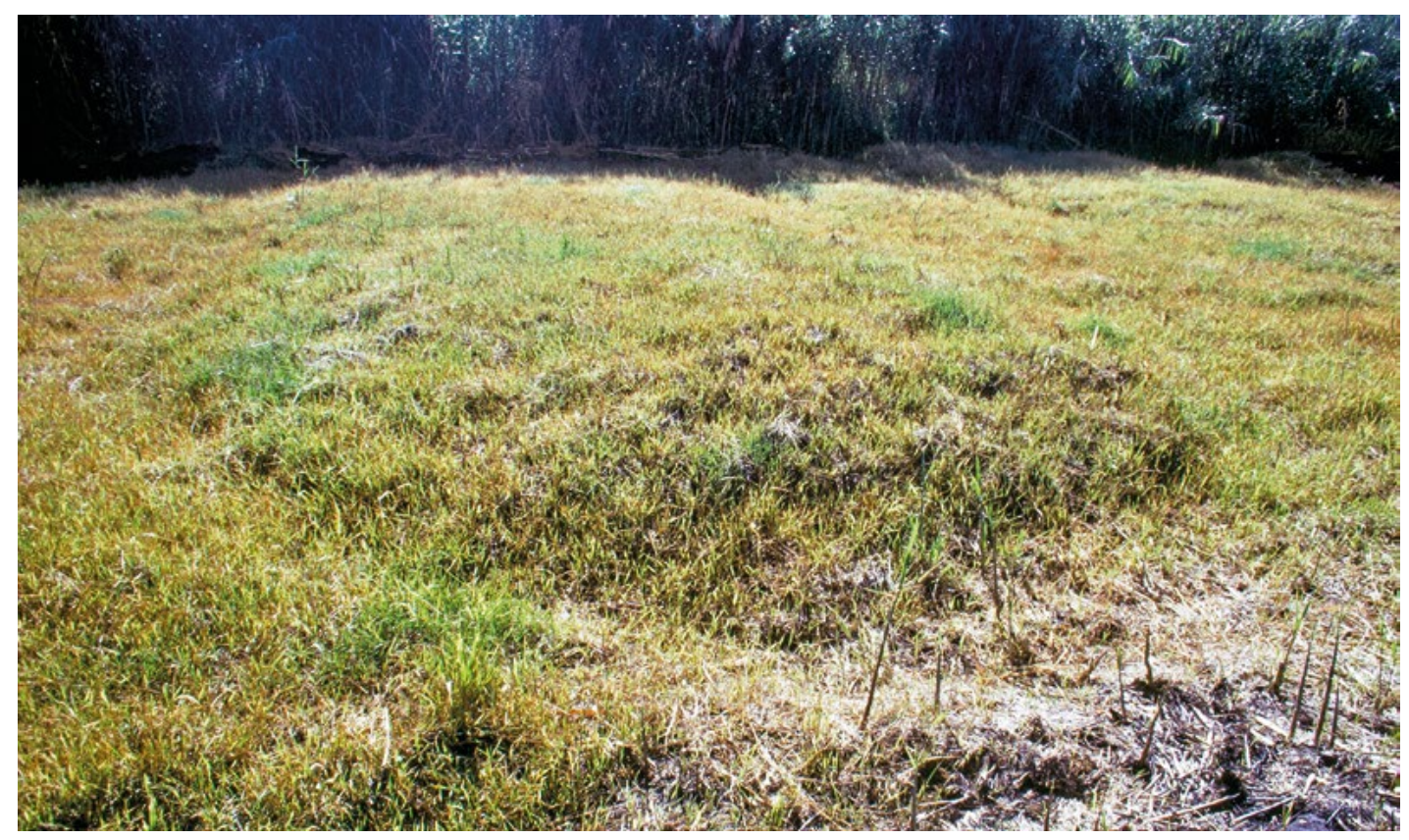

Figure 17.2 A mounded house site revealed at the swamp surface at the southern end of block B9 (see Fig. 17.3 for general location) after the removal of the swamp grass.

Source: Photographer unknown, Kuk archive, 1973. 


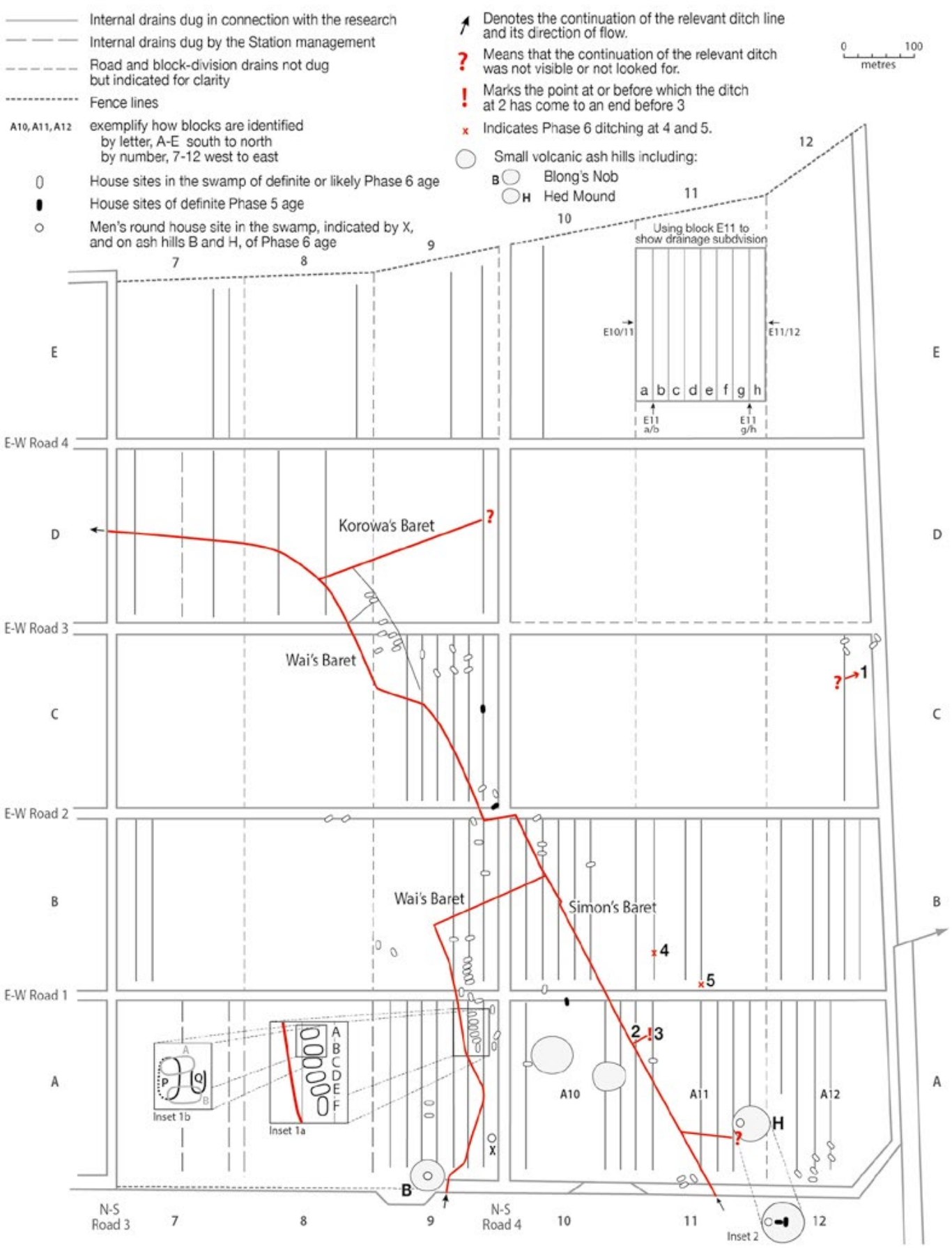

Figure 17.3 The distribution of known house sites of Phases 5 and 6 in the eastern half of Kuk Swamp. Inset 1 a shows the house sites of Phase 6 where excavation of swamp housing was concentrated, specifically at Houses A, B and $F$. Inset $1 \mathrm{~b}$ shows Houses $P$ and $Q$ found under Phase 6 Houses $A$ and $B$ and until very recently accepted as Phase 5 . Inset 2 shows two houses of late Phase 5 on Hed Mound.

Source: Jennifer Sheehan, CartoGIS Services, College of Asia and the Pacific, ANU. 

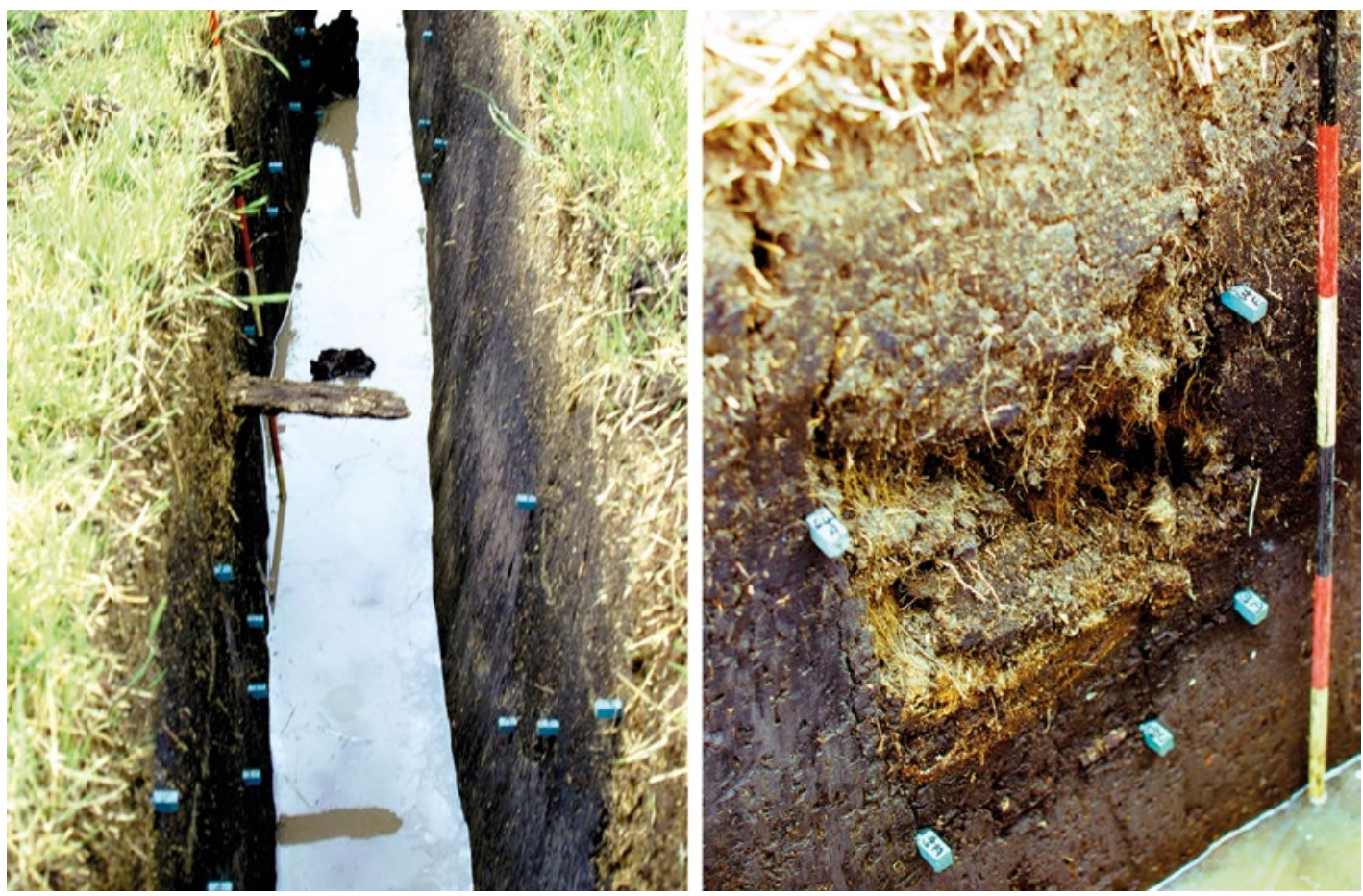

Figure 17.4 Two photographs of a Phase 6 housing area at drain A12c/d (for which see Fig. 17.3).

The ranging pole is graduated at $200 \mathrm{~mm}$ intervals. Left: Looking south along drain A12c/d cutting through an area of Phase 6 housing and exposing house timbers in the process. Right: The ditch of a house exposed in the east wall of drain A12c/d. The looseness of the earth that fills the ditch and its heavy penetration by roots are evidence of the youthfulness of the feature.

Source: Photographer unknown, the Kuk archive, 1974.

As the dry season got under way and drainage proceeded, such features came to register themselves ever more clearly on the swamp surface as the felted peat that formed it shrank with the draining and the drying. We took advantage of the situation to look systematically for house mounds, among other evidence, along, between and, later, beyond the courses of Wai's and Simon's Barets. We came across a few other house sites by chance elsewhere over the rest of the season. The only grouping we found in the swamp in subsequent years was in the southeast corner of the Station as the result of digging drains A12c/d and d/e in 1974 (Fig. 17.3; cf. Fig. 17.4).

The distribution of house mounds in Figure 17.3 is striking in two respects. For one thing, most of them are strung out along the eastern side of Wai's Baret, which during Phase 6, the presumed sweet potato phase at Kuk (see Chapter 16), saw drainage and cultivation restricted to the shallower swamp to its west. Since it would make sense for cultivators to live close to their gardens, there was reason to think that all the houses visible immediately to the east of the channel belonged to Phase 6. In addition, there was the fencing along the eastern bank of Simon's Baret, discovered during the 1973 season and interpreted (see Chapter 19) as marking the western boundary of grazing land for pigs and serving to keep them there.

The second striking feature of the distribution of the house mounds is that some of them fall into seemingly orderly clusters, contrasting with the random distribution of recent houses described by Vicedom, admittedly in a dryland context, in the opening paragraph of this chapter (Vicedom and Tischner 1943-48; 1983). Indeed, when Andrew Strathern brought a group of Kawelka elders to see one of those clusters under archaeological investigation in 1972 at the northern end of block A9g (Fig. 17.3 Inset 1a), he mischievously used the term haus lain to compare it to the linear arrangement of houses at Lutheran missions in the district (cf. Strathern 1971: 8, footnote 1). 


\section{Relative chronology and absolute age}

While the visible house mounds along Wai's Baret might, as argued, belong to Phase 6, there were indications from the surface evidence that they were not all of the same age, within the 200 or so years, that Phase 6 had lasted. Thus everywhere some mounds were more clearly defined than others, with flatter surfaces and sharper edges and a deeper dip of the peat surface above the house ditch, all suggesting that they were younger. However, there was a problem in establishing when mounds in different locations were occupied in relation to each other. Given that the phase to which the visible mounds were thought to belong was recent and of limited duration, radiocarbon dating was not precise enough a tool to employ for the purpose. It was suggested that thermoluminescence dating might be the answer, using the heated stones from earth ovens and other features associated with individual houses to supply a relative chronology. During the second season of Ron Lampert's investigations of houses, in 1973, such a programme was initiated.

Ovenstones from four adjacent house sites-A, B, P and Q - at the northern end of block A9g (Fig. 17.3 Insets 1a and 1b) were provided for Terry Bell, a doctoral student at The Australian National University who was beginning research into thermoluminescence dating in Australia and New Guinea (Bell 1978). The excavations at the four house sites are discussed below. House B was a prominent mounded site whose associated features - ovens, fireplace and house ditcheshad been excavated in 1972 and any finds from there, including cooking stones, recorded and retained. Towards the end of the 1972 season, Lampert dug exploratory trenches into the mound to investigate its structure and earlier history. The most important result of this was the discovery of evidence of two earlier house sites, $\mathrm{P}$ and $\mathrm{Q}$, beneath. These were the subject of full investigation in 1973, requiring the northward extension of the 1972 excavation area. The extension involved the excavation of House A (see Fig. 17.3 Inset 1a), a surface mound like House B, though less prominent, which overlay the northern end of House P. The evidence for earlier and later house sites on the spot encouraged the exercise of ovenstone dating. So did Lampert's report of Tibito Tephra in the fill of the house ditches of both $\mathrm{P}$ and $\mathrm{Q}$, which might therefore predate the fall of the tephra and belong to Phase 5, while Houses A and B postdated it and belonged to Phase 6 . Laurie Lucking, a graduate student from the University of Minnesota, became responsible for the three-dimensional recovery and record of ovenstones for the dating exercise.

In the event, the technique was unable to do what was asked of it (Bell 1976). While it proved possible to date the cooking stones to the general period some 300 years ago indicated by the presence of Tibito Tephra, their use for the chronological ordering of the houses from which they had been collected was impossible because of the large range of uncertainty in the individual ages. This seems to have been due to the particular composition of the stones used in ovens in the area.

Besides the two Phase 5 houses that Lampert's excavations were thought to have identified, there were three other examples where Tibito Tephra was associated with the fill of Phase 5 house ditches exposed in the walls of Station drains (shown in black in Fig. 17.3). This contrasts with the more than 40 cases distributed across the site where house sites were cut by the digging of Station drains with no signs of Tibito Tephra at all. On grounds of probability alone, this suggests that Phase 5 houses were of much more infrequent occurrence than those of Phase 6 . This conclusion would be supported by the fact that the three Phase 5 houses in question, whose ditches were associated with Tibito Tephra in exposures in drain walls, seem not to have been visible at the surface, in contrast to a majority of the house sites overall. What is more, the evidence seemed to indicate a post-Tibito Tephra date for the clustering of house sites. In Chapter 15, this is attributed to changes in the location of settlement and cultivation following the adoption of sweet potato as the staple, which marked Phase 6 off from Phase 5, when it has been argued that yams were a main crop. 


\section{Investigations of houses at Kuk}

This section is based on unpublished data from Ron Lampert, Paul Gorecki and Ed Harris, all of whom worked at Kuk in the 1970s. At the time, Lampert was on the staff of the Department of Prehistory at The Australian National University, where his field records of 1972 and 1973 are housed in the Kuk archive, together with the text of a lecture summarising his 1972 season (Lampert 1973). Paul Gorecki was a PhD student of the University of Sydney, who in 1977-78 investigated settlement and agricultural site-formation processes mainly through observation and enquiry of the Kuk community some 45 years after European contact (Gorecki 1982). Ed Harris was a PhD student at University College London, who developed the Harris Matrix (1979: vii, Appendix 2) in the early 1970s to cope with the complex stratigraphic records of excavations in Winchester (UK), on which he had been employed. This project led him to take up research of his own into the principles of archaeological stratigraphy, of which his work at Kuk was part (1977, 1979: 65, Fig. 19). The text that follows represents a recent attempt to pull together the evidence from these three sources and draw some conclusions. The recent nature of the attempt, together with the loss of some 1973 records, discussed later, explains the error made about the chronology of houses at Kuk Swamp published a decade ago (Bayliss-Smith et al. 2005: 118).

\section{Lampert 1972}

The house mound cluster B-F, on which Lampert began work in 1972, is at the northern end of block A9g (Fig. 17.3 Inset 1a). As plotted ahead of excavation, four of the house mounds, B-E, were between 14.5 and $16 \mathrm{~m}$ in length and 5.5 and $6.5 \mathrm{~m}$ in width. They were subrectangular in plan and consistently slightly higher at the western end than the other, as well as parallel to each other, fairly evenly spaced and at right angles to Wai's Baret. The fifth mound, F, at the southern end of the group, was also subrectangular, but shorter $(11.5 \mathrm{~m})$ and narrower $(5 \mathrm{~m})$, and parallel to Wai's. House B (Fig. 17.5) was almost totally excavated and House F (Fig. 17.6) substantially so, together with some of the house ditches and adjacent floors at House C (Fig. 17.5) and E (Fig. 17.6). House $\mathrm{D}$ was not touched at all. As a separate and more straightforward exercise, Lampert excavated the site of a round house (Fig. 17.7) discovered by Winifred Mumford at the southern end of Block A9h (see Fig. 17.3 at X) from surface indications.

Because from the outset the well-defined profiles of the mounds suggested them to be of no great antiquity, and in light of Vicedom's descriptions of Hagen houses in the 1930s (Vicedom and Tischner 1943-48: 158-171; 1983: 177-193), Lampert (1973: 2) combined his archaeology with ethnographic observation and enquiry of contemporary houses at Kuk and vicinity. Some he recorded in detail, with measured plans and elevations of all structures both internal and external. He paid particular attention to the parts of a structure likely to be registered in the ground archaeologically, like pits and posts. All these contemporary houses were on dry land, with one exception, a house for women, their children and pigs built right at the margin of the swamp, with a deep ditch and a raised floor, just like the house mounds that he was excavating.

\section{House mound $B$}

In the light of the ethnographic evidence, past and present, Lampert felt able to interpret his archaeological findings at House B (Fig. 17.5) as indicating a women's house of the same general type as the swamp-margin house just mentioned, the people living at one end and the pigs in somewhat larger quarters at the other, the two separated by a partition, as suggested by a line of postholes that he found across the middle of the house that he had excavated (see B on Fig. 17.5). 


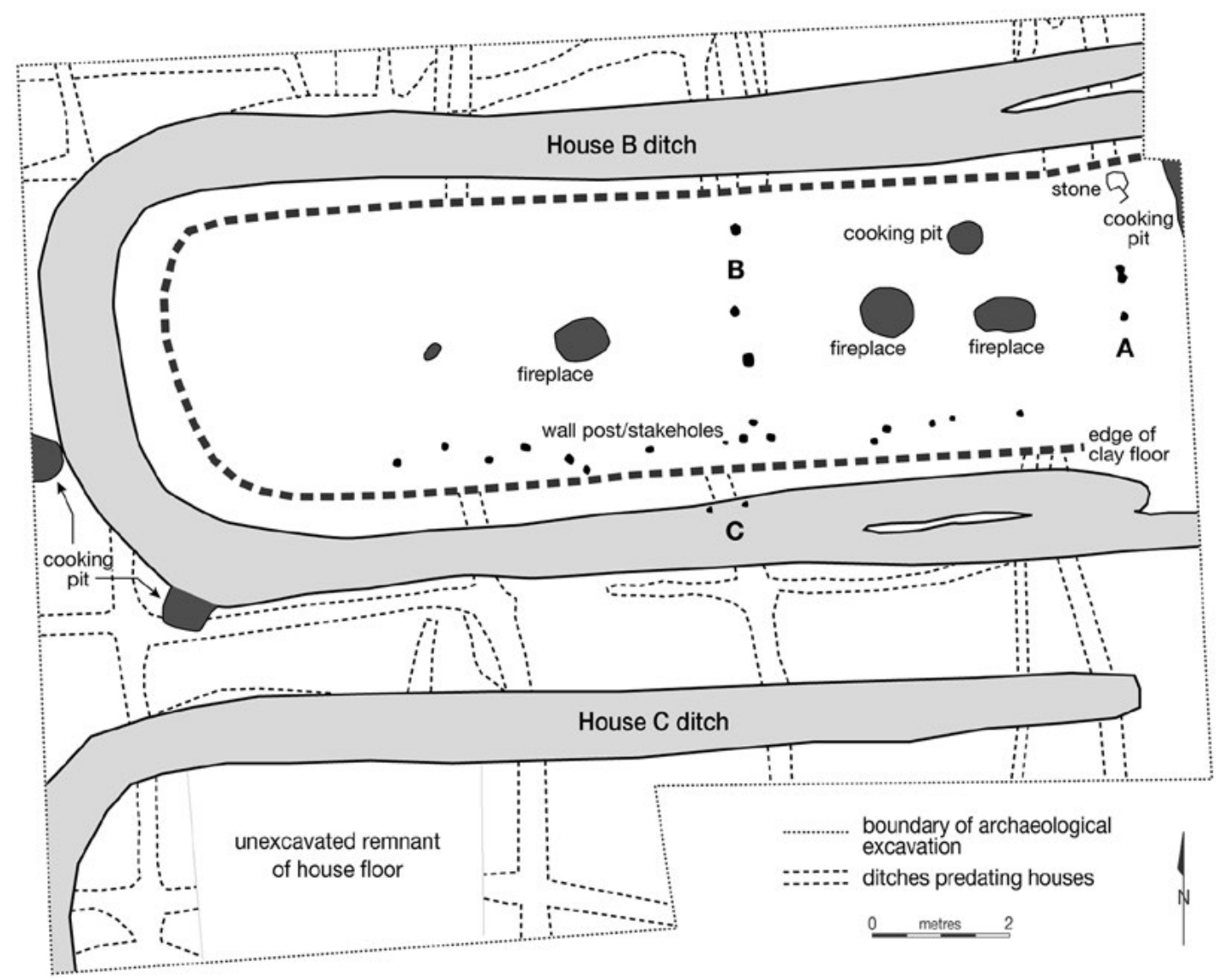

Figure 17.5 Plan of House B and part of C as revealed by excavation in 1972.

Source: Drawing by Anthony Bright, Cartography, College of Asia and the Pacific, ANU, from field originals by Winifred Mumford and Ron Lampert, final production by Jennifer Sheehan, CartogIS Services, College of Asia and the Pacific, ANU.

The horseshoe plan of the House B ditch and three postholes in a rough N-S line between its eastern ends (above A) suggest that the house had a straight termination at the east, contrasting with the curved one at the west. This would be an example, like House F (Fig. 17.6), of Gorecki's veranda house (see Fig. 17.14), from whom I borrow the term. There would have been a central line of posts supporting the ridgepole of the house, but it seems that only some of the holes dug for this purpose here were recovered by excavation.

The dotted features running at right angles to each other are the ditches of Phase 4 cultivation plots over which the houses were built (see Fig. 14.11).

The clear separation between people and pigs conforms to modern practice, as observed by Lampert at Kuk in the early 1970s, but seems to be at variance with Vicedom's report of roomsharing by women and pigs in the 1930s and their use of a single entrance. However, Figure 17.5 shows the rough position, at $\mathrm{C}$, of two upright posts in the north wall of the house ditch just west of the partition presumed to have divided the pigs from the humans. According to Lampert's workmen at the time, the uprights could mark the position of a former bridge across the house ditch to a doorway, implying in this case a separate entrance for the pigs. There was no evidence of stakeholes for pig stalls, but stakeholes do not regularly survive archaeologically and stalls were indeed not always provided (Vicedom and Tischner 1943-48: 167, 168; 1983: 186, 189). Sharing of the space between pigs and humans, as reported by Vicedom, might explain 
the fireplace beyond the partition. On the other hand, Lampert (1973: 3) talks about fires being lit in small hearths to warm and dry pigs after foraging on a wet day, while noting an absence of cooking pit and cooking stones in the pig space.

Excavations in the front of the house produced some interesting finds. Among the charcoal of one of the hearths there charred sugarcane was found, together with the end of a tuber (Fig.16.13; cf. Swadling 1981: 49), immediately and understandably attributed to sweet potato by the finders, but subsequently identified as lesser yam (Dioscorea esculenta) (see Chapter 16; on these charred plant remains in general see Lewis, Denham and Golson 2016). The house ditch had been redug (as had that of House $\mathrm{C}$ ) and, at least on the south side, lengthened. At the end of the earlier segment, five women's short digging sticks were found. As Lampert (1973: 5) noted, these were expectable finds at the bottom of a house ditch, since he saw women put their sticks there, at their own houses, after the day's work, to soak up water and keep them fresh and weighted for the morrow.

\section{House mound F}

For Lampert, House F (Fig. 17.6) could be readily interpreted as a men's house on the basis of its shorter length (because not providing space for pigs), the absence of women's digging sticks in the stretches of its ditch that were excavated and the presence of stone axe flakes in what he calls the central working area. By this he seems to have meant the living area marked by cooking pit and hearth, though this was by no means central, but towards the north end of the house. There was only a hint of evidence of a partition between the front activity area and presumed sleeping quarters at the rear and no evidence of house walls. We may note that at $11.5 \mathrm{~m}$, House F was only 3.5-4.5 $\mathrm{m}$ shorter than the other four mounds of the group we are discussing, not the degree of difference to be anticipated from Lampert's statement (1973: 3) that men's houses were only a third to a half the size of women's. As at Houses B and C, there was definite evidence for the recutting of the house ditch at House F. At the north end of its west leg, the later, shallower ditch extended some $0.7 \mathrm{~m}$ further than the earlier deeper one.

It was because of their similarity in size, orientation and appearance to House $\mathrm{B}$ and in the absence of contrary evidence from the limited excavations at Houses $\mathrm{C}$ and $\mathrm{E}$ that Lampert interpreted Houses C-E as women's houses with pigs, like House B. Of these four women's house mounds and that of the proposed men's House F, Lampert (1973: 2) concluded that their 'even spacing and consistency of form suggested from the outset that all five structures were contemporaneous and of the same social complex'. The individual houses, he said (1973: 5), matched those in use today, the unusual feature being 'their spatial arrangement, laid out in the pattern of a formal village'. 


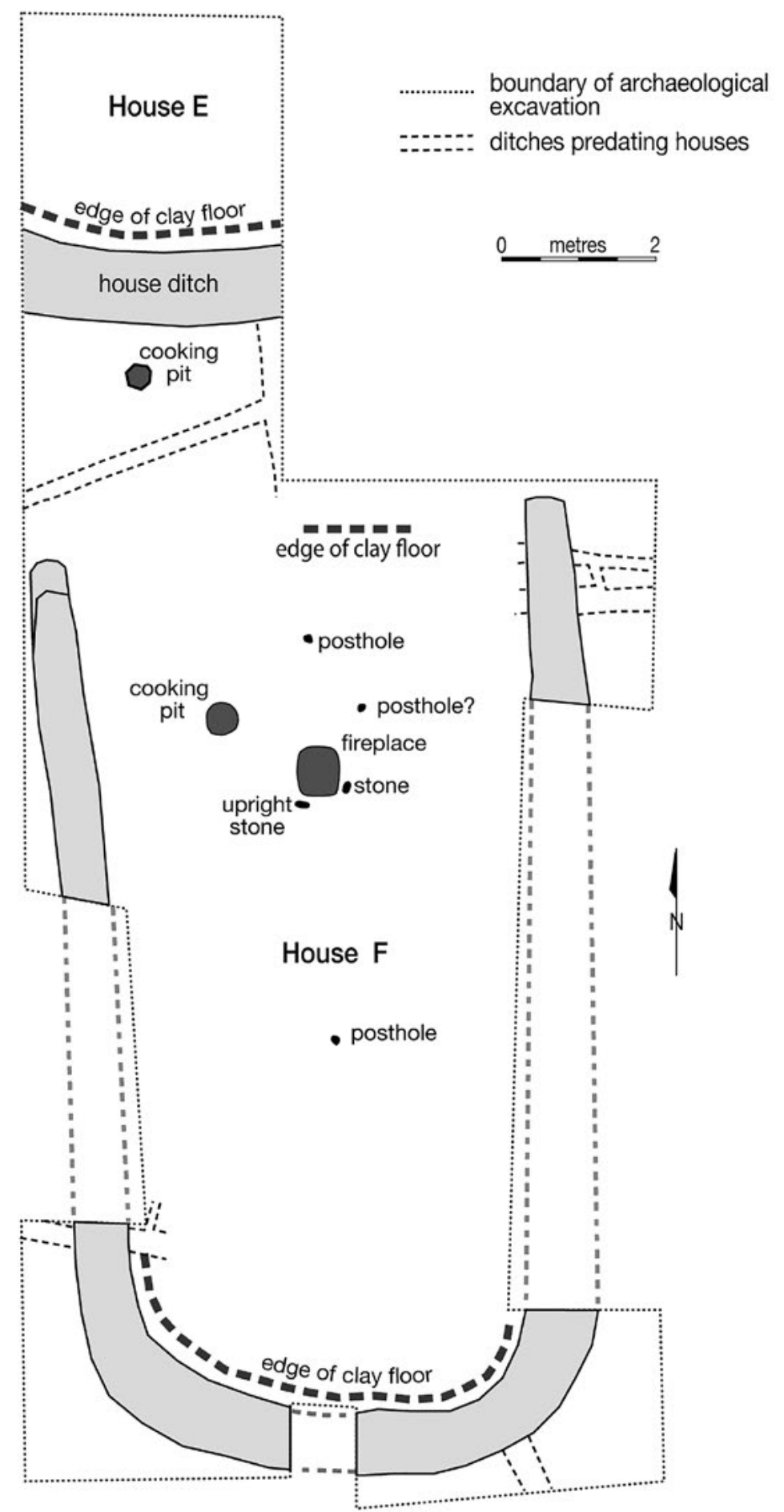

Figure 17.6 Plan of House F and part of E as revealed by excavation in 1972.

Lampert interpreted House F as a men's house, in part because it was shorter, if not dramatically so, than House B (Fig. 17.5). Note that there is a cooking pit as well as a fireplace in the front part of the house. For cooking pits and men's houses see the end of the next section. The horseshoe plan of the house ditch and the trace of the edge of a clay floor between the ditch ends suggest a straight termination to the structure at the north contrasting with the curved one at the south. Like House $B$ (Fig. 17.5), this is a veranda house and, again like House B, its house ditch was redug and extended, at least at the end of its western leg.

Source: Drawing by Anthony Bright, Cartography, College of Asia and the Pacific, ANU, from field originals by Ron Lampert, final production by Jennifer Sheehan, CartoGIS Services, College of Asia and the Pacific, ANU. 


\section{Lampert and a men's round house excavation of 1972}

The earthworks of men's round houses, consisting of a sunken floor surrounded by a bank except across the entrance (cf. Fig. 17.7), were found on some of the small hills of volcanic ash at the margins of the swamp. There were such earthworks on top of Blong's Nob (B on Fig. 17.3) on the southern boundary of the Station at the end of blocks A9c and A9d, which gave commanding views over the swamp to Ep Ridge (Fig. 16.10). Unfortunately, these earthworks were destroyed when material was quarried from the hillock in the course of Station development in 1972. Similar earthworks were found on a low but extensive rise in block A7 while the course of Kupalg's Baret (Phase 2, Denham's channel 105) was being mapped (see Fig. 12.3 upper).

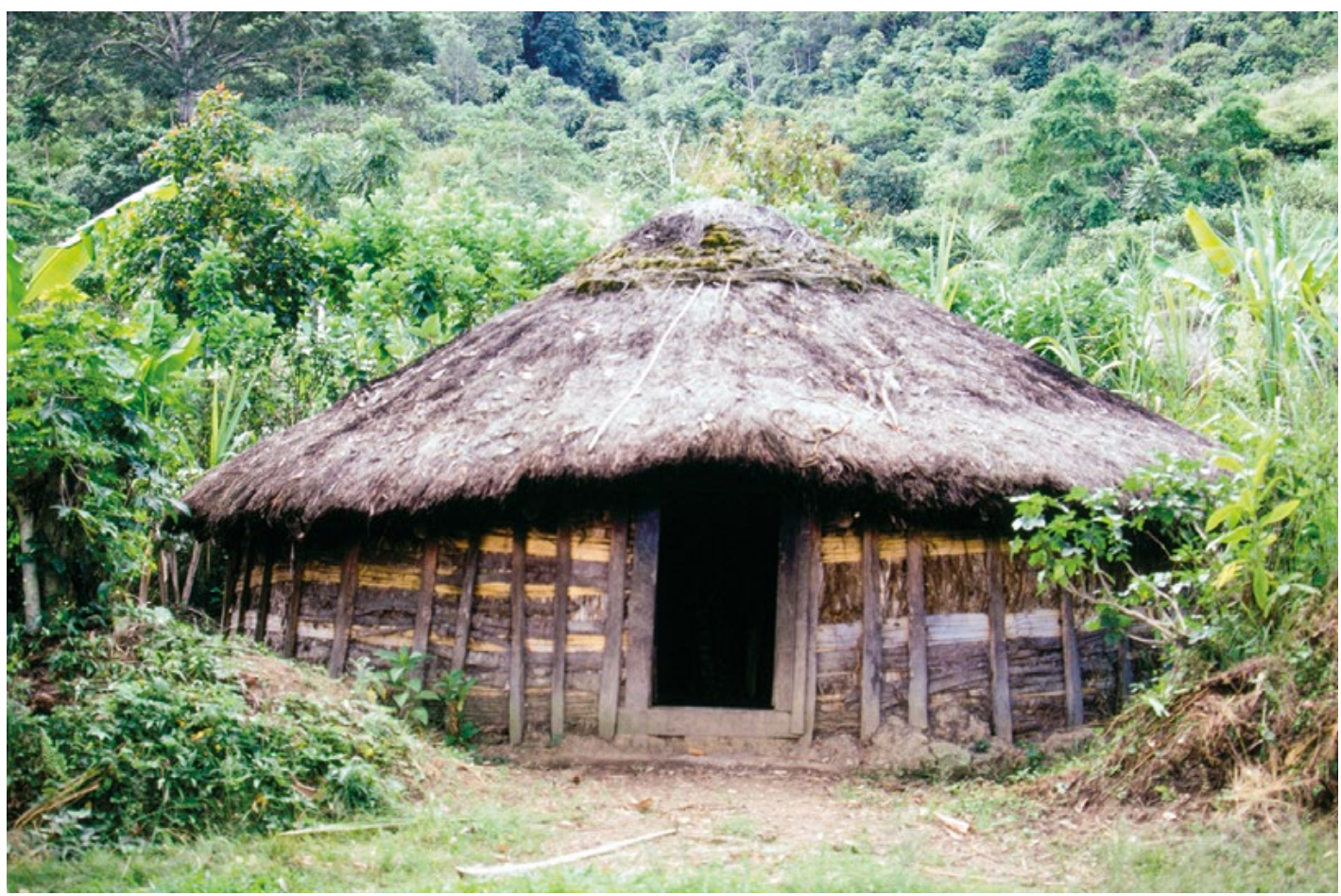

Figure 17.7 A men's round house at a ceremonial ground at the foot of Ep Ridge on the north side of Kuk Swamp.

Source: Photograph by Paul Gorecki, 1978.

In the course of the field reconnaissance during the prolonged dry season of 1972, when the map of house sites shown in Figure 17.3 was largely produced, a single example of a round men's house was discovered in the swamp itself, towards the southern end of block A9h (at X in Fig. 17.3). It appeared as a low flattish circular mound up to $0.4 \mathrm{~m}$ above the level of the neighbouring swamp, with an accompanying ditch and outer bank appearing as a slight dip and a slight rise of the surface except at the north, where excavation subsequently showed the entrance to have been (Fig. 17.9). This surface evidence suggested that the house belonged to Phase 6, like Houses A-F already discussed, though not necessarily strictly contemporary with any of these. No excavation took place below the house floor, but the house ditch gave no evidence of having been redug. 


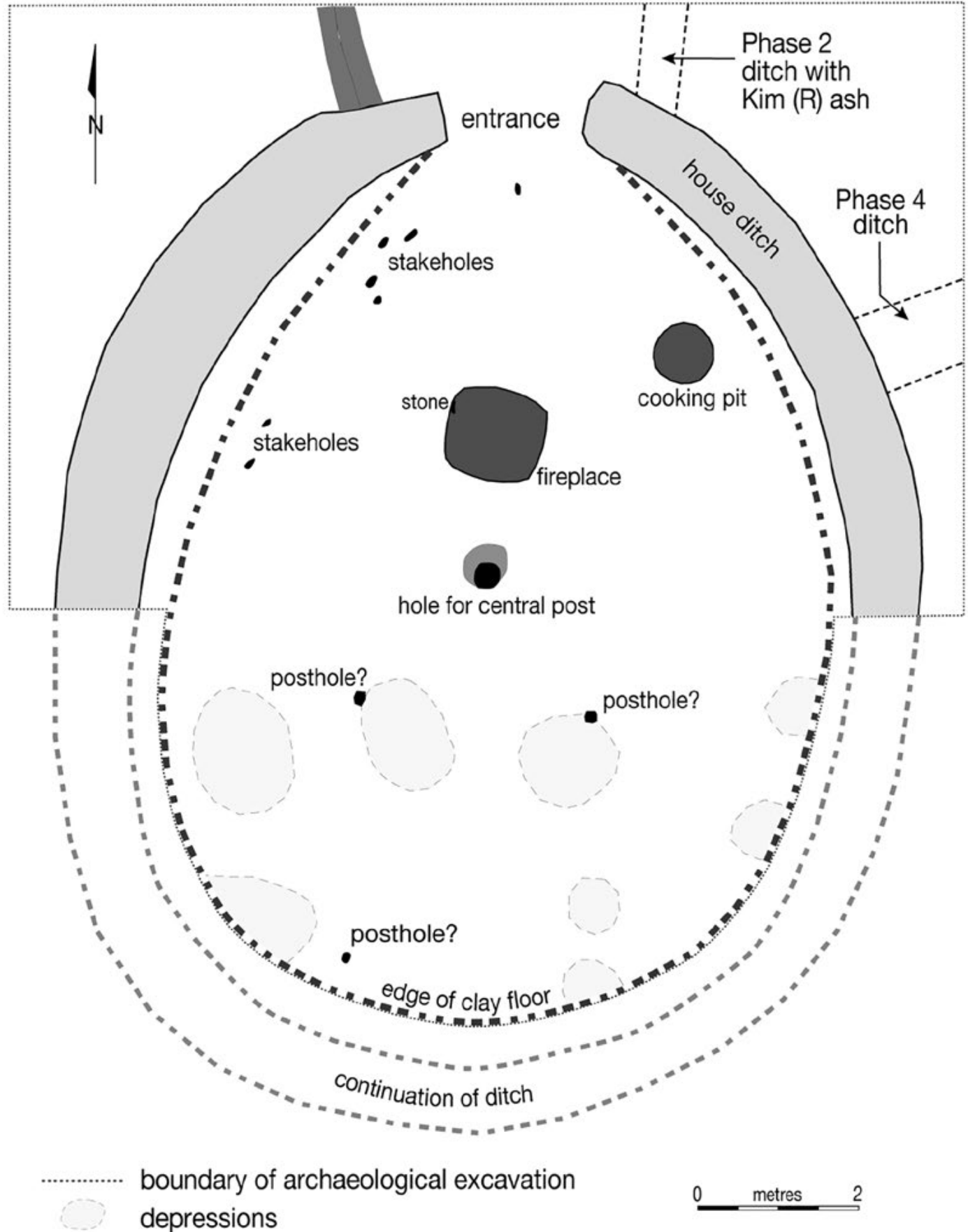

Figure 17.8 Plan of a men's round house as revealed by excavation in 1972.

Round houses supported by a central post were one of the types of house built by a clan leader at a ceremonial ground, which the doorway would have faced. The hole for the central post is clear in the house excavated by Lampert and some stakeholes from the wall are seen at top left.

Source: Drawing by Anthony Bright, Cartography, College of Asia and the Pacific, ANU, from field originals by Winifred Mumford and Ron Lampert, final production by Jennifer Sheehan, CartoGIS Services, College of Asia and the Pacific, ANU. 


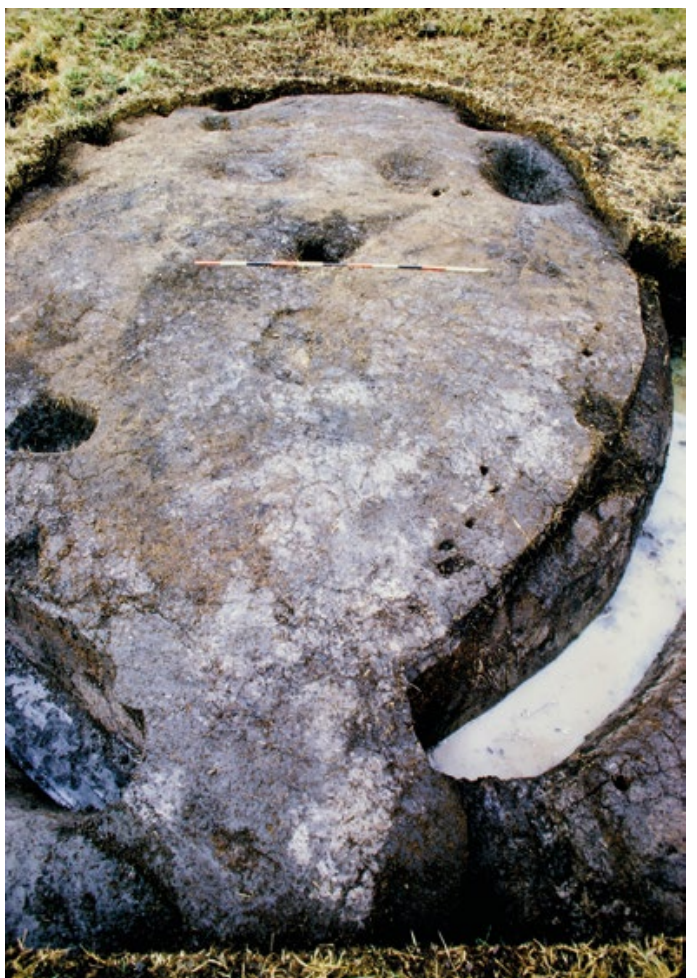

Figure 17.9 Looking south over the round house of Figure 17.8 after excavation.

The image shows a causeway giving entry to the house between the ends of the surrounding ditch. An axe fragment was found at the base, near the west wall of the causeway (see Fig. 20.13B). The ranging pole is graduated at $200 \mathrm{~mm}$ intervals.

Source: Photograph by Ron Lampert, 1972.
The front of the house was the living area, equipped with a fireplace and a cooking pit. The significance of the cooking pit is discussed at the end of this section. The back part of the house was the sleeping area and the two possible postholes found there may have had something to do with partitions. Lampert suggested that depressions in the house floor adjacent to these postholes were in fact associated with them and indicated doorways into the bedrooms. Other depressions at the rear curve of the house he thought might simply be soft areas in the make-up of the floor. The visibility of the site at the surface indicates a general Phase 6 date for the structure. The ditch to the west of the entrance that runs northwards was thought by Lampert to be of the same age because it did not seem to continue south of the house ditch.

The cooking pit plotted by Lampert (Fig. 17.7) needs comment. Vicedom says that no cooking was done in men's houses and his plans of men's houses of the 1930s, with their obvious relevance for the pre-contact situation, show no cooking pits (Vicedom and Tischner 1943-48: 166, Fig. 76; 1983: 186, Fig. 76), in contrast to the practice in later times. Lampert's round house excavation, however, produced clear evidence of a cooking pit in a men's house of pre-contact date, as he had previously done at House F (Fig. 17.6).

\section{Gorecki 1977-78}

Lampert's exercise illustrated a number of the problems that Paul Gorecki later highlighted as a result of his fieldwork with the Kuk community in 1977-78. This work included a study of houses and the homesteads of which they were part, where ethnographic evidence and observation (1982: 63-110) were complemented by excavation at living sites of recent remembered occupation (1982: 111-163). The aim was to understand the dynamics in the settlement process that lay behind the material evidence with which the archaeologist had to deal (Gorecki 1982: 65-81). We shall look at three aspects of the evidence: the ethnographic, the archaeological and the ethnoarchaeological.

\section{Ethnography}

Gorecki (1982: 82-84, 109) concluded that the use of ethnographic evidence to help with the interpretation of prehistoric house sites in the upper Wahgi is not straightforward. On the one hand, there are a number of house types described in detail by the missionary Vicedom, who was in the Hagen area from 1934 to 1939 and whose observations were obviously relevant for the period immediately preceding contact (Vicedom and Tischner 1943-48: 158-79; 1983: 177-202). On the other hand, it was evident that significant change had taken place during the contact period, including the disappearance of some house types, the modification of others and the appearance of a few innovations under European influence (Gorecki 1982: 81-110). 
Gorecki described the problem as that of distinguishing the old from the new in the virtual absence of any documentation of the process of change between the 1930s and the 1970s. The danger was one of using anachronistic models in the interpretation of pre-contact structures.

Vicedom recorded three types of dwelling house: a subrectangular house with rounded ends; a similar house but with one end straight; and a round house (Vicedom and Tischner 1943-48, 1983: Fig. 76). With different internal arrangements, the first type could be a family house, a men's house or a women's house (numbers 1, 2, 4 of Fig. 76) and the second a men's or a women's house (numbers 3 and 5 of Fig. 76). Vicedom says that there were pigs in all women's and even in some family houses. The round house (number 6 of Fig. 76) was exclusively a men's house, only built at a ceremonial ground, as was the type of men's house with one straight gable end (number 3 of Fig. 76). The third type of men's house, a subrectangular structure with rounded ends (number 2 of Fig. 76), could be built both at the ceremonial ground and in the general settlement area.

By Gorecki's time, the round type of men's house (Fig. 17.8) was of lesser importance, while that with one straight gable end had ceased to exist as a men's house. The subrectangular house with rounded ends, Gorecki's oval house, was the most common kind. Some of them served as dwellings for women and children or for families (Fig. 17.10), while others were for women and pigs, where the two had separate entrances to separate quarters (Figs 17.11-17.13). The main differences between the two sorts concerned the features connected with pigs. This included the space allocated to them, which tended to make the oval house with pigs rather longer than the other type, though Gorecki found considerable overlap in size.

We can best appreciate the problem that Gorecki identified in the relationship between ethnographic and late prehistoric houses of the upper Wahgi by considering a particular aspect of Lampert's excavations. Thus the ditch at House $\mathrm{F}$ is horseshoe-shaped in plan, undug across the northern end of the house, while an edge of the clay floor there suggests that the structure to which it belonged had a straight termination to the north, not a rounded one as at the south (Fig. 17.6). The situation at House B (Fig. 17.5) seems to have been the same, though only one eastern end for the earlier ditch was actually excavated, and neither of the ends for the later ditch. In the case of this house, the evidence for a straight termination to the structure is a row of three postholes, marked by A on the plan, in line with the eastern end of the earlier ditch. Excavation indicates a horseshoe plan for the ditch of House $\mathrm{C}$ as well (Fig. 17.5).

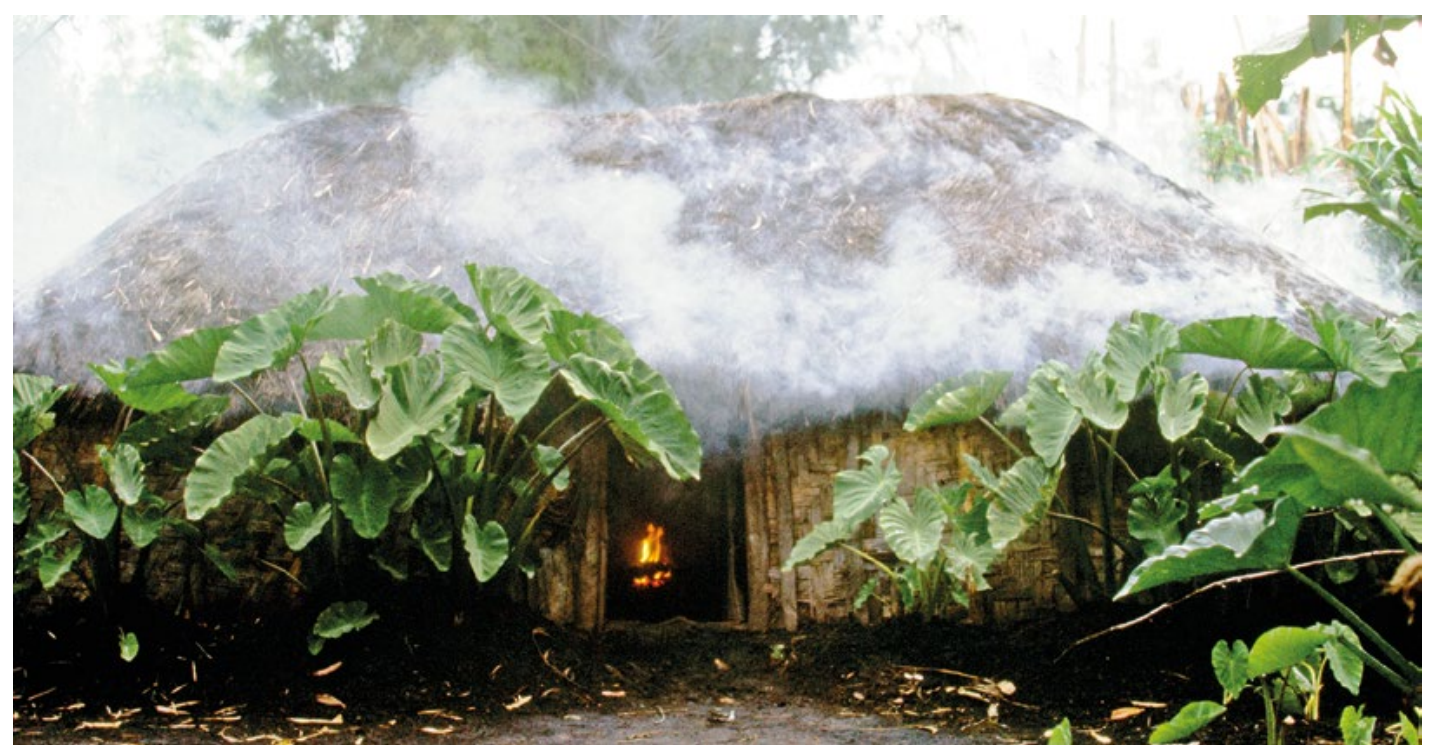

Figure 17.10 Early morning view of a family house with rounded ends and central doorway.

Source: Photograph by Paul Gorecki, 1977. 


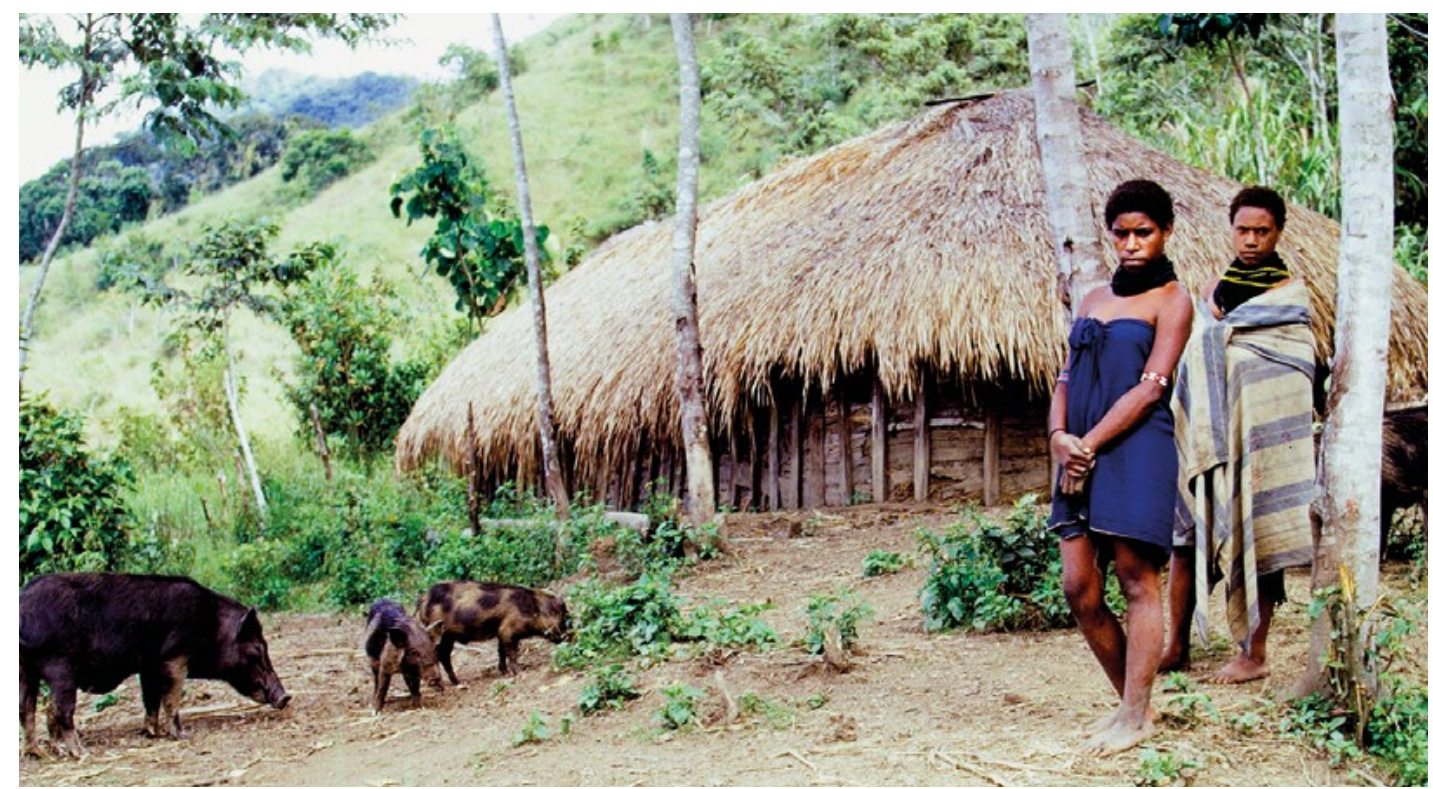

Figure 17.11 Women's long house with stalling for pigs, at the southern foot of Ep Ridge at Kuning, 2-3 km NNE of Kuk.

Source: Photograph by Ron Lampert, Kuk archive, 1970.

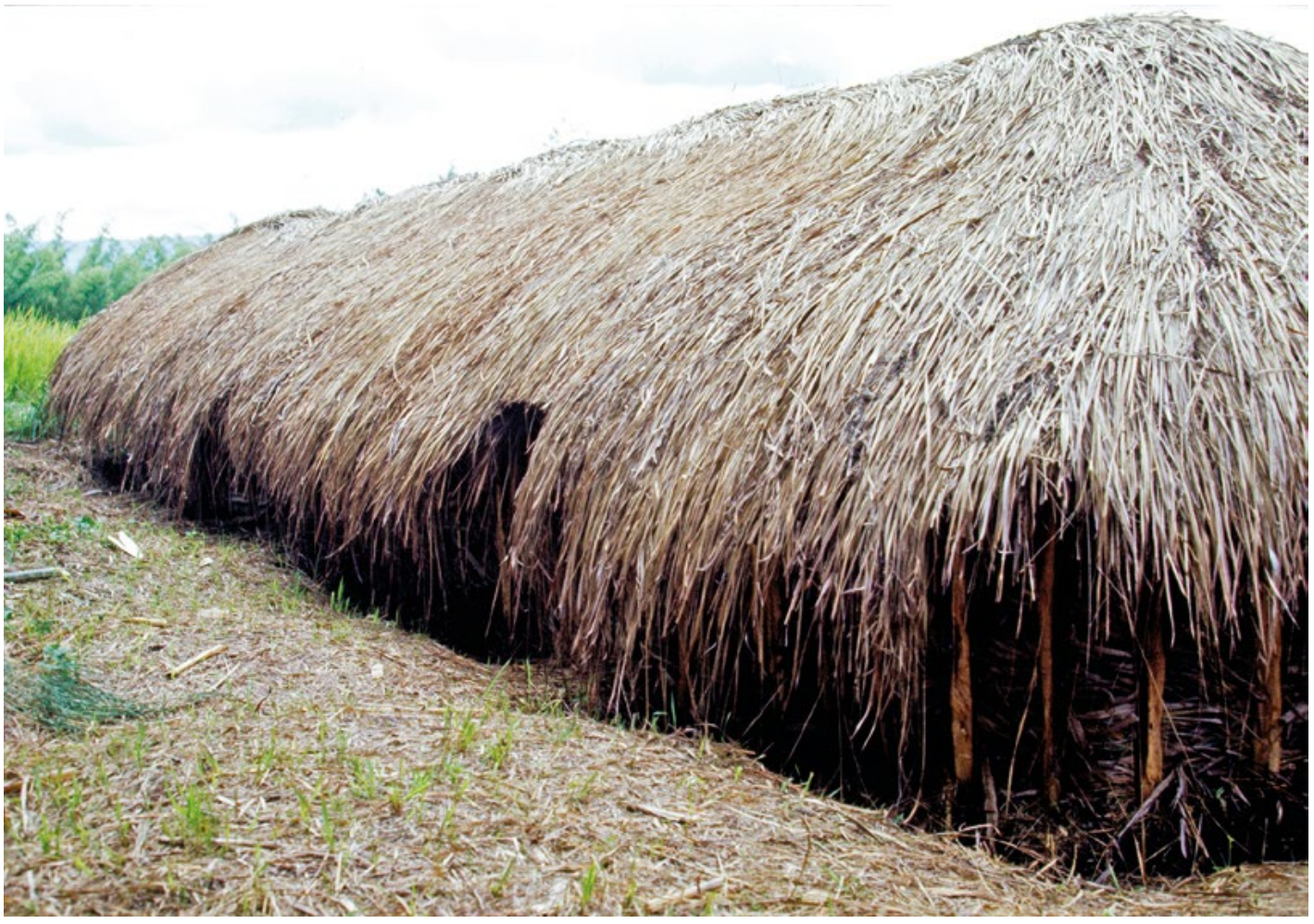

Figure 17.12 Newly built women's house on low-lying ground at Kuk, with separate entrances for people and for pigs.

Source: Photograph by Paul Gorecki, 1977. 


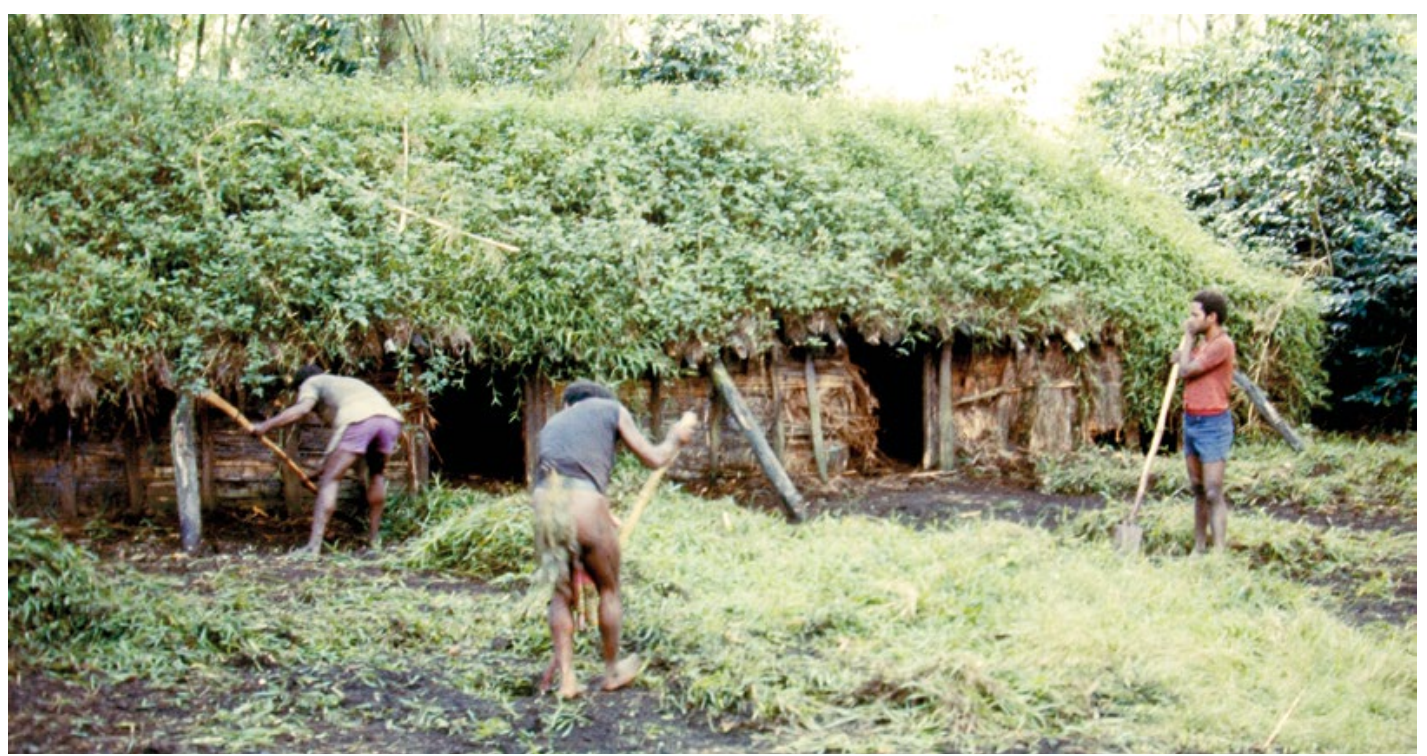

Figure 17.13 A former women's long house with separate entrances for people and for pigs. Source: Photograph by Paul Gorecki, 1977.

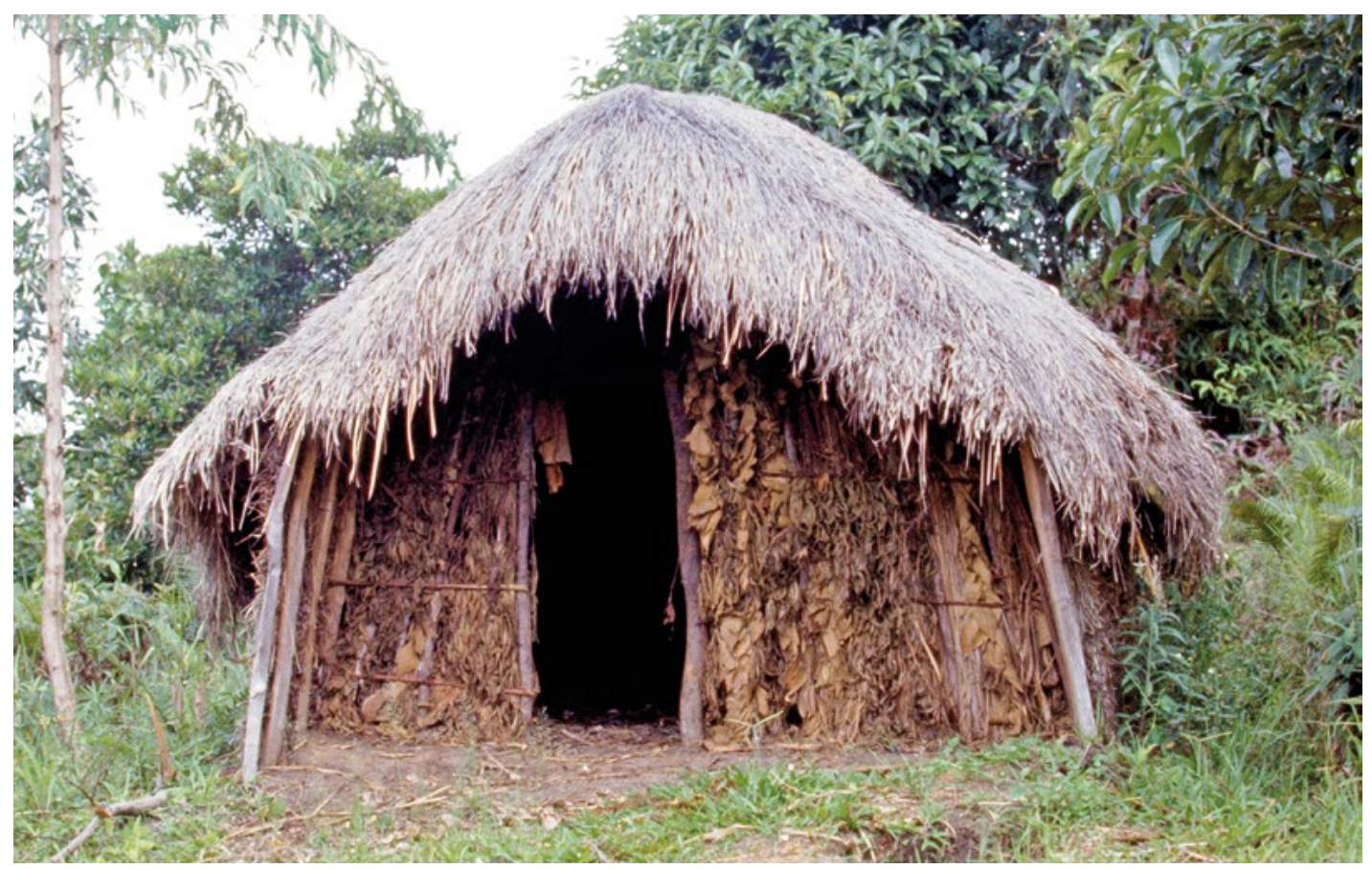

Figure 17.14 A variety of veranda house at Kuk.

Source: Photograph by Paul Gorecki, 1977.

These house plans are reminiscent of what Paul Gorecki (1982: 96-98; Fig. 17.14 here) called the veranda house during his 1977-78 work at Kuk. Gorecki also used this name for one of Vicedom's three types of dwelling house, the subrectangular one with one end rounded and the other straight. There were two varieties of the type, with different internal arrangements serving in the one case for men and in the other for women, children and pigs. In Vicedom's plans and descriptions of these two varieties (Vicedom and Tischner 1943-48: 170, Fig. 76.3; 1983: 191, Fig. 76.3 for the men's house; and 1943-48: 171, Fig. 76.5; 1983: 192, Fig. 76.5 for the women's house), there is a living room at the front provided with an open or only partially 
closed gable and backed by a partition wall to the rest of the house, which at times was essentially the outside wall. In the veranda houses described by Gorecki, there is an open veranda at the front (Fig. 17.14), separated by a wall with doorway from the living room and the rooms behind it, the veranda acting as a temporary store, shelter and toolshed.

By the time of Gorecki's fieldwork, the veranda house was a family house that was losing favour. Gorecki recorded only 10 during his work at Kuk, all of them within the boundaries of one clan, and he considered this an unrepresentative sample.

\section{Archaeology}

In the last section, we saw from Vicedom how the same types of dwelling house could with different internal arrangements serve different functions. These internal arrangements in some cases involved walls and partitions that might leave some archaeological trace of their former presence but in other cases devices that left no trace at all, such as merely laying a pole on the floor. In fact, Lampert (1973: 4) and Gorecki (1982: 92), together with Ed Harris (1977: 1617), whose house excavations at Kuk in 1977 we consider later, all report that they found little evidence for internal structures, or indeed external walls, in their work. This was the case whether the sites were on dry land, as they were for Gorecki and Harris, or in the swamp, as they were for Lampert.

Lampert (1973: 5) notes from his observations of dryland structures at Kuk that wall staves rarely entered the subsoil to have their presence registered there and this is likely to have been the case at house mounds in the swamp, where the floor might have been raised as much as $0.4 \mathrm{~m}$ by spoil from the house ditch. Gorecki (1982: 287-288) makes a distinction between features dug and those driven into the subsoil, the latter tending to be quickly lost to the archaeological record, the former preserved through the actual removal of material and its subsequent replacement by something visually different. Harris (1977: 17-18) offers somewhat different arguments for the situation but admits that whatever the cause, many aspects of New Guinea housing do not survive archaeologically.

What are likely to survive are house ditches, central postholes for the ridge pole, fireplaces and cooking pits. At existing or recently abandoned houses that he observed or excavated, Gorecki (1982: 157-158) found sufficient regularity, on the one hand in the number and location of central posts and on the other in the distances between them, hearths and cooking pits, to allow formal and functional interpretations of the structures involved. These interpretations could be tested against the distribution of cooking stones, by far the most numerous of the associated objects of domestic life. Lampert (1973: 5) had already noted how cooking stones were confined within cooking areas by walls and piled up against them when not in use and so could provide evidence for the location of walls for which no structural evidence was preserved.

\section{The ethnoarchaeology of settlement}

Gorecki pointed out that the number and type of houses comprising a homestead might vary greatly and could change over time. As an example (Gorecki 1982: 74-78), he took the history of a Kuk homestead that he recorded from its inhabitants through enquiries on the spot about the buildings that had formed part of it. The homestead was in existence by 1969, inhabited by Rea and his wives and children, and was radically expanded and rearranged around 1971, when $\mathrm{Ru}$ came with his wives and children to join his subclansmen. When Gorecki left Kuk in 1978, the occupation whose history he had recorded could not have much exceeded a dozen years in length.

The pre- and post-Ru phases of habitation saw the regular replacement of buildings, more as a result of fire than decay. In the earlier period, fire destroyed two subrectangular houses, two menstrual houses and a toilet, while decay accounted for one subrectangular dwelling house 
and one women's house (with pigs). In the later period, a house for women and pigs, three sub-rectangular dwelling houses and one menstrual house were burnt down and two toilets succumbed to decay.

As regards the replacement houses of the later period, all of them were built at the same place as their predecessors, but in the case of the three subrectangular dwelling houses only two locations were involved, since the first and second houses in a sequence of three burnt down on the same spot. These two houses belonged to Ru and Gorecki described how, in building the third in 1978, $\mathrm{Ru}$ reused the central postholes and the oven pits of the previous house, but totally rebuilt the two hearths at a new location some $0.8 \mathrm{~m}$ away from the previous ones. Gorecki noted that in other cases at Kuk, he saw buildings of a different type replacing the structures that had previously occupied a particular location.

Sometimes a replacement structure was built right next to the old one. This was the case with two subrectangular dwelling houses of the first phase (Gorecki 1982: Fig. 8, J). These were appropriately spaced for an owner systematically to use the old house as a source of firewood for the new and as little as a metre might separate them (Gorecki 1982: 78-79). Simultaneous occupation of houses required more space between them.

\section{A new look at the 1972 excavations}

In the light of the work described above, Gorecki (1982: 160-161) questioned the general conclusions that Lampert (1973) had drawn from his 1972 excavations. He did so on the basis of access to Lampert's detailed plan of the excavated features at House B and the partially excavated House $\mathrm{C}$, as well as the relevant field notes.

The point about close spacing of houses made in the final paragraph of the previous section is relevant to Gorecki's suggestion (1982: 160) that the parallel Houses B-E (Fig. 17.3 Inset 1a) with house ditches only 1.5-2 m apart, represent successive, not simultaneous occupations. Also important in this respect is the possible evidence for different phases of occupation at Houses B and $\mathrm{C}$, represented most directly by the redigging of the house ditches there. Gorecki thought there might have been at least three houses at House B, of at least two types, and two houses at House C, of perhaps the same type. In the process, Lampert's (1973: 5) 'pattern of a formal village' becomes Gorecki's (1982: 161) picture of a single family reusing house sites in the same fashion as today.

Gorecki did not find convincing evidence for Lampert's interpretation of Houses B-D as houses for women and pigs. He thought that only the suspected length of some houses, particularly what he called the 'earlier' on House B, suggested that we might be dealing with this type. However, Lampert's records indicate that, to judge from the redug house ditch, the longest house at the mound was the later (or latest), not the earlier (or earliest), since the eastern end of the final house ditch went further east than that of at least the southern arm of the earlier ditch (Fig. 17.5). Strictly speaking, because it goes into unexcavated ground, we do not really know whether it curved around to form a closed end to the house or, as at House F (Fig. 17.6) and other excavated house ditches of the mound group, terminated with the front end of a veranda house.

\section{Lampert 1973}

At the end of his 1972 season, Lampert dug two test pits through the floor of House B, producing evidence of curving ditches that suggested that there were two houses underneath. He investigated this situation in 1973 (Fig. 17.15), not only confirming the presence of the two houses, which he called P and Q, but claiming them to be of Phase 5 date by the evidence of Tibito Tephra 
in the fill of their accompanying ditches. House $\mathrm{P}$ had a ditch that appears to have encircled it. The other structure, House Q, somewhat shorter, was a veranda house, opening north. The two houses were parallel to each other and close together.

The 1973 investigations meant extending the House B excavation area of 1972 to the north, totally removing the House B floor and taking in the surface mound called House A in the process. The plans of these excavations have been long lost, but I have used Lampert's field notebooks of the time to reconstruct the layout that is displayed in Figure 17.15. There was sufficient detail in the 1973 notebooks to tie in with the information about the southern ends of Houses P and Q that had been recorded in 1972 and about the departure of the House P ditch from the 1973 excavation area near its northwest corner and so give confidence in the general size and placement shown for them in the figure. The same is not as much the case, however, with the Phase 6 house, A, which was not touched by the 1972 excavations. Given the circumstances overall, I have only plotted hearths and cooking pits for which information about age and location is sufficient or where there is some other purpose in doing so. In any case, at the time of his excavations, Lampert frequently found it difficult to discriminate features belonging to the earlier houses from those intrusive from later phases of housing and other activity. As a result, there are limits to what can be said about the structures uncovered in 1973.

Although not fully excavated, House A appears to have been one of the veranda type that was prominent among the investigated houses of the 1972 season and, as with most of those, its house ditch had been at least partially redug. Though not completely exposed, the surface and excavated evidence for it suggests a structure more like House F than the others of the group.

House P, built in a space $15 \mathrm{~m}$ long and more than $5.5 \mathrm{~m}$ wide as defined by its encircling ditch, could in terms of shape be compared with family, men's or women's houses as described by Vicedom (numbers 1, 2, 4 of Fig. 76, Vicedom and Tischner 1943-48 and 1983), the first and third also providing room for pigs. Its potential length falls at the extreme end of the range of Gorecki's oval houses used by women or a nuclear family (1982: 87 and Table 6), but around the middle of that of the similarly shaped structures that Gorecki called woman and pig houses (1982: 93 and Table 7).

House Q, of veranda type in an $8 \times 4.5 \mathrm{~m}$ space defined by its associated horseshoe-shaped boundary ditch, is oriented north-south, parallel to House P and just over $4 \mathrm{~m}$ to its east. In terms of Gorecki's reinterpretation of Lampert's 1972 excavations, this was far enough apart for the buildings to have been simultaneously occupied. For Lampert, its small size, just over half the length of House P, would indicate a men's house and the central location of the fireplace might support this. In addition, a lump of red ochre excavated from the house ditch was explained by Lampert's workmen as used in connection with men's ceremonial display of pearl shell decorations (cf. Strathern and Strathern 1971: 20, 26, Plate 9 and Colour Plate 13). There was a fireplace at the southern end of House P, though not originally thought to belong to it, which proved to be associated with stones of a type that his workmen told Lampert had traditionally been used only to line the hearths in men's houses. Note, however, in the preceding paragraph the size and shape of House P were seen as suggesting its use for accommodating pigs as well as people.

Figure 17.15 shows the northern end of the eastern arm of House $Q$ as stopping short of a purported latrine, so that the stratigraphic relationship between the two is unknown. Neither is there any information about the structure's place in the general stratigraphy of the site, so that we do not know whether it is likely to belong to Phase 5 or Phase 6. The latrine is generally thought of as being a European introduction, i.e. later than Phase 6 at Kuk. The feature in question is a vertically sided pit some $0.75 \mathrm{~m}$ in diameter and $0.55 \mathrm{~m}$ deep. The bigman Ongka identified it as a latrine and his opinion is never to be lightly dismissed, though by shape and size 
it could have been an oven pit. Harris describes as a cesspit a rather deeper pit on Hed Mound (1977: Fig. 9J). It dates within Periods V-VII of the mound complex (Fig. 17.17C-E), which, as discussed in the next section, belong to Phase 5 of the Kuk sequence and are thus definitely pre-European. However, the source of the latrine identification in this case is unknown.

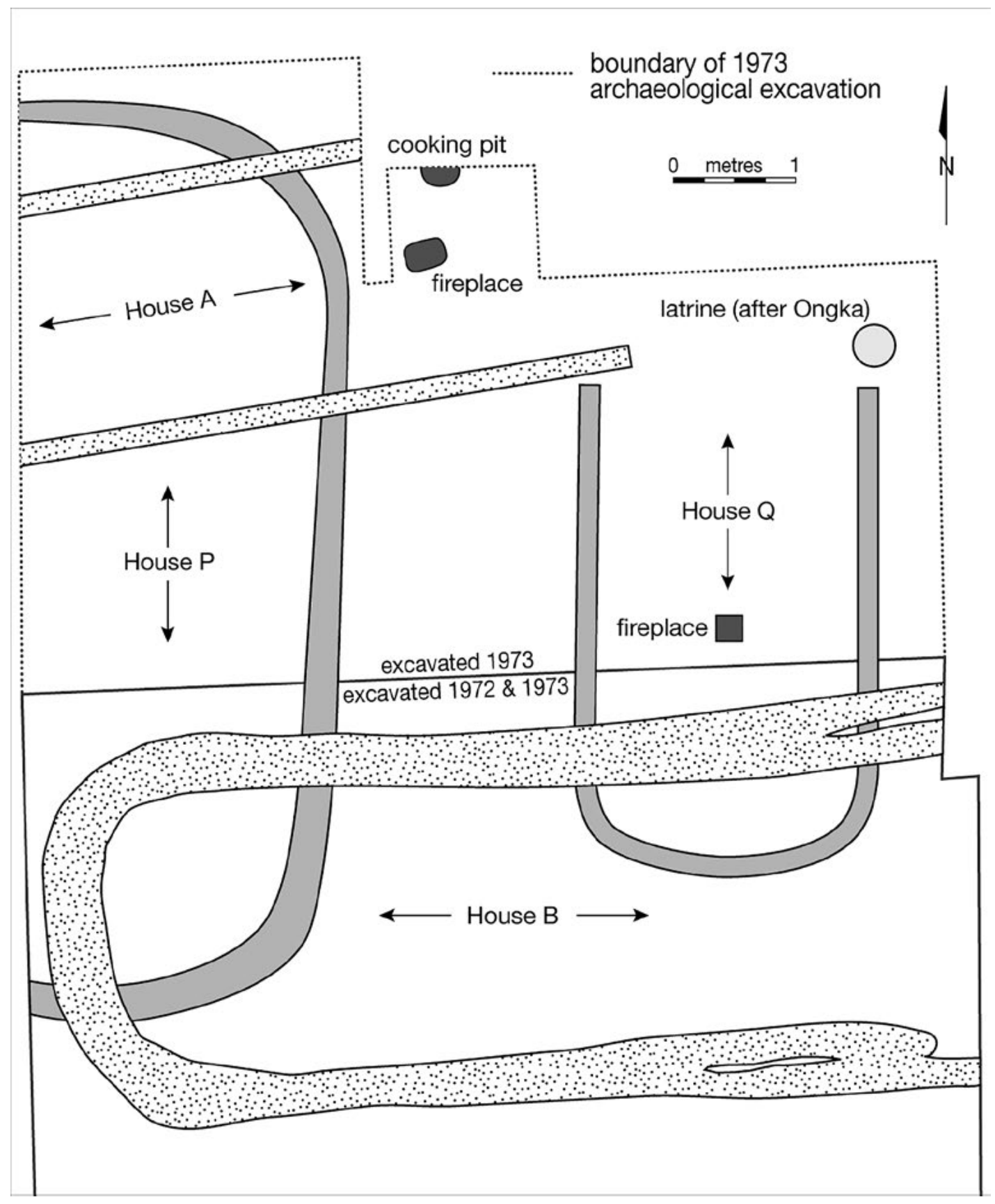

Figure 17.15 Plan of Houses $P, Q$ and part of A as reconstructed from Ron Lampert's records of his 1972 and 1973 excavations.

Because of the loss of the field plans of the 1973 excavations, the position and direction of the boundary ditch of House $A$ is less certain than those of Houses $P$ and Q, the location of whose southern ends had been established in the 1972 excavations. However, a 1972 plan of house sites visible at the surface at the northern end of blocks A9g and A9h shows House A as narrower and more diagonally placed across block A9g than House $B$, as it is in the reconstruction here.

Source: Drawing by Anthony Bright, Cartography, College of Asia and the Pacific, ANU, with amendments by Jennifer Sheehan, CartoGIS Services, College of Asia and the Pacific, ANU. 
There has been a recent reevaluation of Lampert's conclusions as to the chronology of Houses A, B, P and Q in relation to the fall of Tibito ash (Lewis, Denham and Golson 2016). For Lampert, A and B were younger than the ashfall and so Phase 6 in the Kuk sequence, while $\mathrm{P}$ and $\mathrm{Q}$ were older and thus Kuk Phase 5. The evaluation was made in the context of an archaeobotanical analysis of charred plant remains found in association with the houses. New AMS results for House Q overlap with those for House B and are supported by those from Bell's (1976) palaeomagnetic exercise, suggesting that the Tibito ash in the ditch of House Q is not in primary position (see Tables 3 and 1, respectively, of Lewis, Denham and Golson 2016).

\section{Harris' excavations on Hed Mound 1977}

The hill on the line of drain A11g/h towards the southern end of block A11 (Fig. 17.3H) was extensively excavated by Ed Harris in 1977 (Fig. 17.16) and called Hed Mound by his workmen (Harris 1977). It was a complex site where successive structures had been superimposed at the surface of the basal clay, with little stratigraphic differentiation between them in the shallow deposits above and not much stratigraphic connection between them spatially.
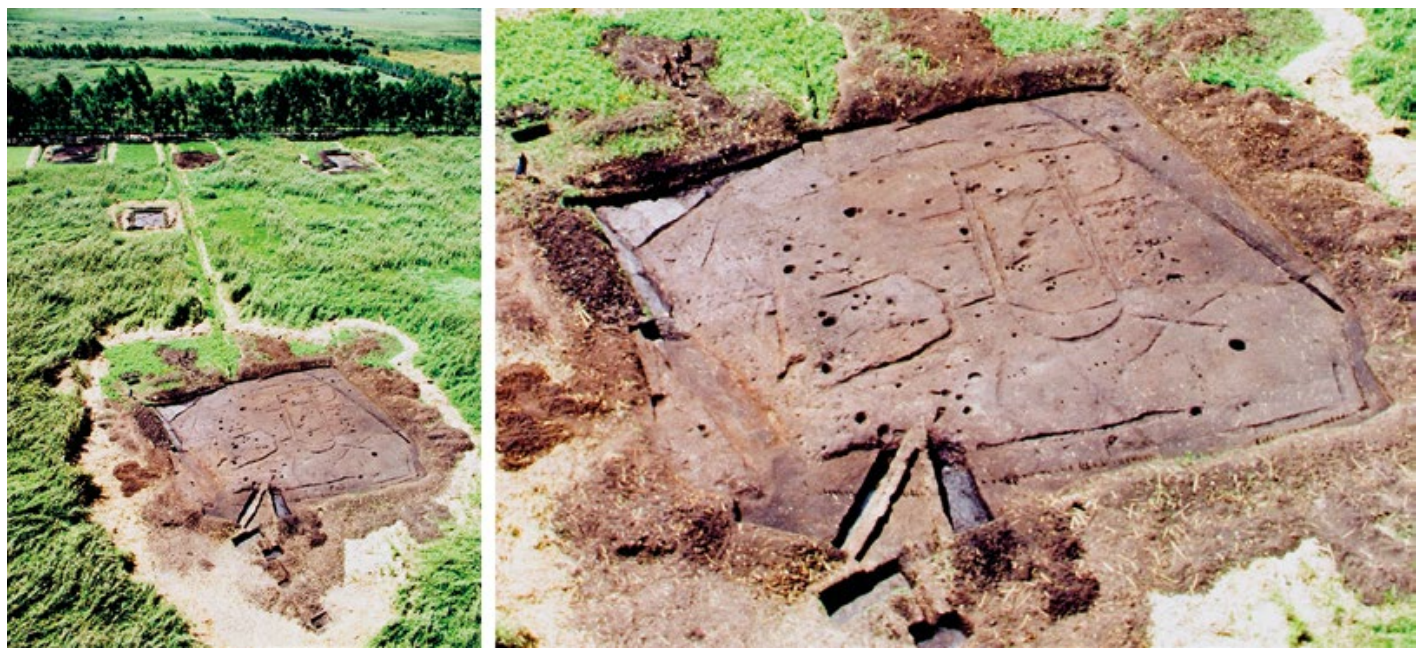

Figure 17.16 Aerial view just east of north over the completed excavations on Hed Mound.

Source: Photograph by Ed Harris, Kuk archive, 1977.

Harris identified eight periods of activity overall at Hed Mound (1977: 4-11, Figs 1-3) and displayed the major features inferred for each period in Figure 7 of his 1977 report. This has been adapted here as Fig.17.17 to help with discussion of the site.

\section{Periods $I-I V$}

Periods I-III (Harris 1977: 4-7) saw activity at the margins of Hed Mound connected with drainage and cultivation in the swamp during Phases 2, 3 and 5 of the Kuk sequence. For Harris (1977: 7-9), the first firm evidence of housing at the mound is Period V and subsequent rebuilding constitutes Periods VI and VII. The houses were archaeologically best defined by the shallow eavesdrip ditching dug horseshoe-fashion along two walls and around one end (Fig. 17.17C-E). Some of the remnants of shallow ditching assigned to Period IV of the Hed Mound sequence, immediately preceding the house ditches of Periods V-VII, show similar combinations of straight and curving courses (Fig. 17.17B). Harris conceded (1977: 7) that the features as a whole might have belonged to houses predating Period V, though his first suggestion was that they were ditches with an agricultural function. Gorecki's opinion (1982: 161) was that they were for houses, not agriculture, though it should be noted that dryland agricultural ditching made an appearance in Phase 5 at Kuk and elsewhere (see Chapter 15, 'Interpretation').

\section{terra australis 46}



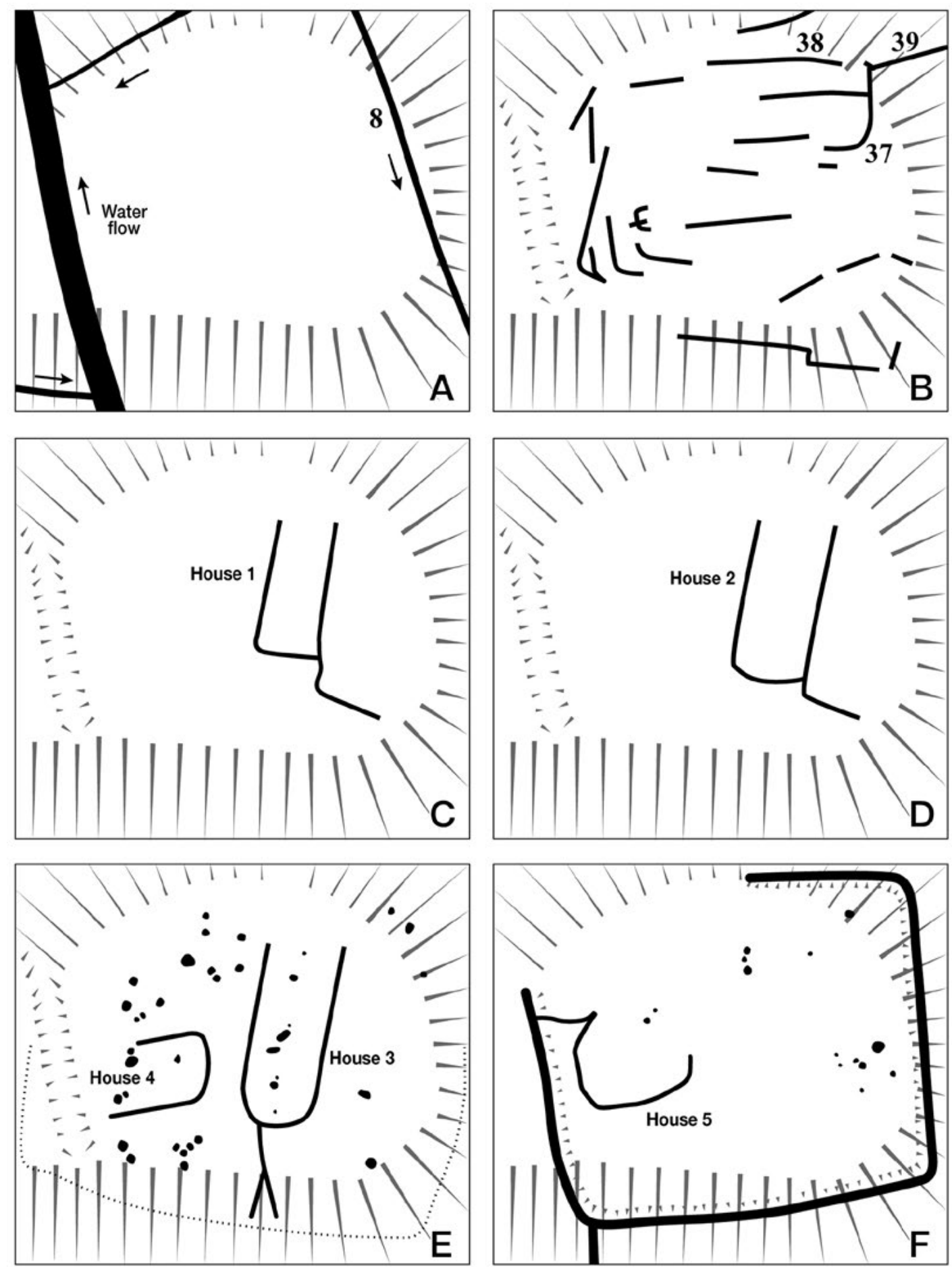

Figure 17.17 Periods III-VIII of the archaeological sequence on Hed Mound.

Source: Jennifer Sheehan, CartoGIS Services, College of Asia and the Pacific, ANU.

There has already been discussion in Chapter 15 (section 'Artefacts, houses and pigs') about features 37-39 of Figure 1 of Harris 1977 (reproduced here as Fig. 17.18) as the most convincing evidence for housing in Hed Mound Period IV, which dates to Kuk Phase 5. The features in question form part of a complex of ditching, up to $0.50 \mathrm{~m}$ wide and $50-100 \mathrm{~mm}$ deep, found widely over the excavated area, though only visible at the surface of the grey clay subsoil that 
occurs sporadically beneath the features of Periods V-VII (Fig. 17.17B). There was limited evidence as to the stratigraphic relationship between the majority of these ditch features, which Harris (1977: 7) admits to having been 'somewhat arbitrarily assigned' to Period IV, as well as between them and the four field ditches that formed the total archaeological content of Period III (Fig. 17.17A). The strongest evidence of relationship is provided by features 36 and 37 of Period IV and feature 8 of Period III, a substantial field ditch that had Tibito Tephra at the top of its fill and so was dug early in Kuk Phase 5. Figure 1 of Harris' 1977 report (Fig. 17.18 here) shows feature 8 cutting across features 36 and 37 and thus being younger than them. In recent correspondence, Harris has confirmed his trust in the field drawings on which Figure 1 of the 1977 report is based. Since this provides support for features 36 and 37 being Period III and feature 8 being Period IV, we might further suggest that Periods III and IV as a whole, as depicted here in panels A and B of Figure 17.17 (3 and 4 of Harris 1977: Fig. 7), should change chronological place. If the structure represented by features 36 and 37 was in fact a house, it would have been a veranda house and with enough space within its proposed defining ditch, $14 \mathrm{~m} \mathrm{~N}-\mathrm{S}$ by $8 \mathrm{~m} \mathrm{~W}-\mathrm{E}$, to have housed people and pigs (see Fig. 17.18).

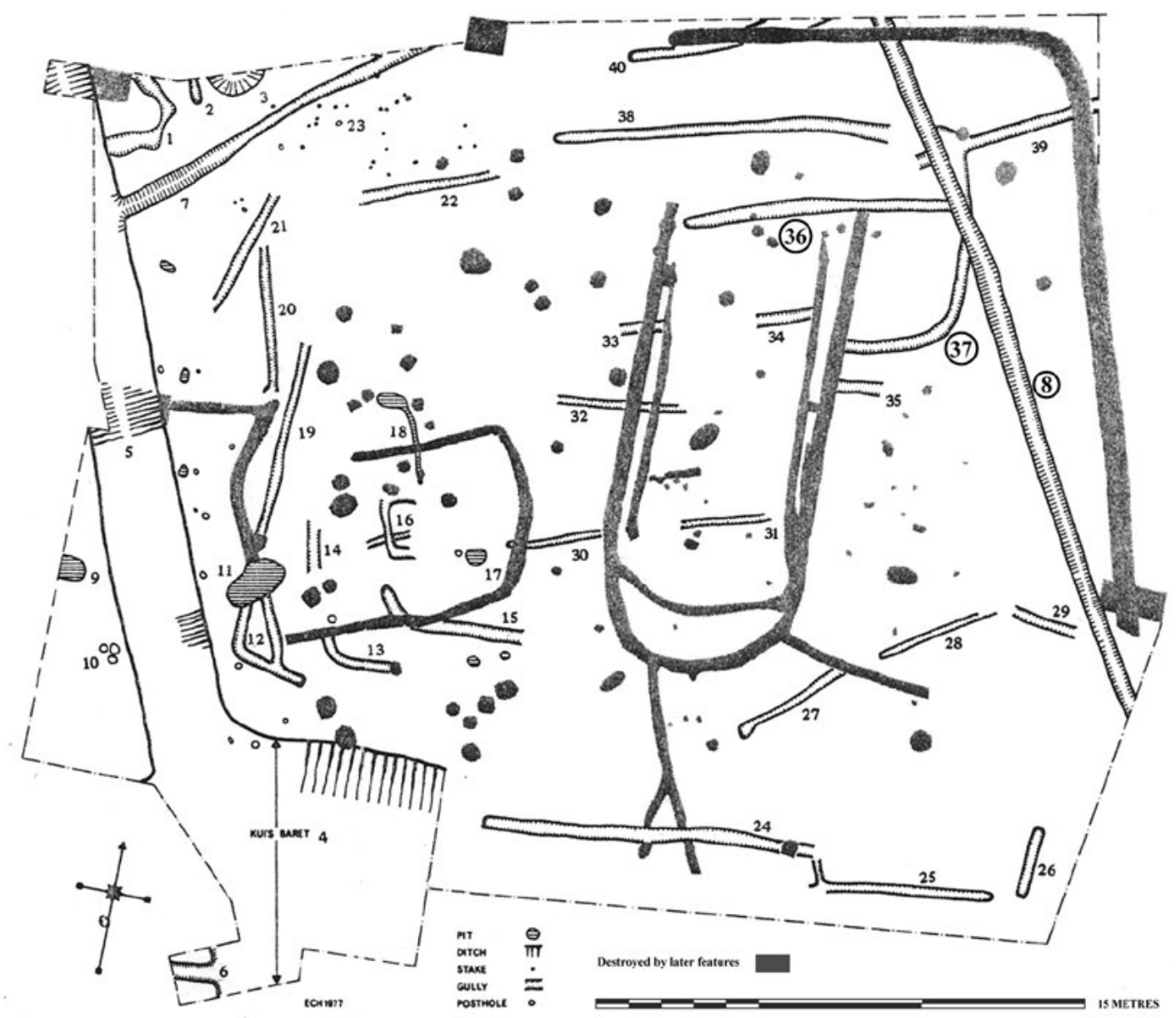

Figure 17.18 Hed Mound, showing features assigned to Periods I-V.

The relationship between feature 8 , on the one hand, and features 36 and 37 , on the other, indicates that feature 8 is later than the others, not earlier, as stated in the explanatory text attached to the original figure and its discussion in panels 3 and 4 of Fig. 7 of Harris 1977 (panels A and B of Fig. 17.17 here).

Source: Jennifer Sheehan, CartogIS Services, College of Asia and the Pacific, ANU. 


\section{Periods V-VII}

The clearest picture of the building sequence of Mound Periods V-VII (Harris 1977: 7-9) is presented by Period VII. At this stage, there was what Harris interpreted as a house for women and pigs running north-south across the top of the hill (House 3 of Fig. 17.17E; cf. Fig. 17.18). The horseshoe plan of the ditching, which provided a building space of $15 \times 5 \mathrm{~m}$, indicated a subrectangular house of the veranda type, like those in the swamp, where the living quarters were at the front. There were some holes for posts that had carried the ridgepole. A fireplace and cooking pits found in the front part of House 3 were appropriate for a women's house, while two irregular hollows in the space behind could equally appropriately be seen as pig wallows. Harris, however, used the model of an abandoned house that he recorded at the northern foot of Ep Ridge (1977: 15) to suggest that House 3 had had living quarters at the two ends and pigs in the middle.

There had been two earlier ditches of horseshoe plan at the site of House 3, representing Periods $\mathrm{V}$ and VI on the mound (Houses 1 and 2 of Fig. 17.17C and D here; cf. Fig. 17.18 and Harris 1977: Fig. 2). Though they were of smaller size than House 3, they were presumed to have had the same layout (Harris 1977: 21) and therefore function.

House 1, the smallest of the three houses built north-south on the same spot, was represented by what were interpreted as the remnants of a house ditch on its long sides, with a now lost outlet at its southeast corner. The house space allowed by the estimated ditch line is $10 \times 4 \mathrm{~m}$. No other features could be assigned to the period of the house. House 2 is represented by even fewer remnants of its suggested house ditch than House 1, except that what is taken as the curved section of its southern end was fully preserved. Like House 1, it is reconstructed as a veranda house, with $12 \times 5 \mathrm{~m}$ available within the suggested line of the ditch. As with House 1, it was impossible to identify other features, internal or external, that were in use at the same time as House 2.

Allowing double the conventional estimates of four or five years for the lifespan of a house, Harris (1977: 13) gave a duration of 30 years for Periods V-VII (citing Lampert 1973: 4 for Kuk and Brown 1972: 34 for Simbu, based on Brown and Brookfield 1967: 130). During this short period of activity, there was another veranda house on Hed Mound (House 4 of Fig. 17.17E and cf. Fig. 17.18; Harris 1977: 9 and Fig. 2), running east-west across its western flank somewhat obliquely to the lines of Houses 1-3, whose lines were only a few metres east of House 4's rounded end. The small size of House 4, half the length of House 3, was consistent with its having been a men's house, with no provision for pigs. There was no way of knowing to which, if any, of the three periods of the women's house it had belonged.

The same was true of a perimeter fence enclosing a habitation area of some $900 \mathrm{~m}^{2}$ centred on these houses (Harris 1977: 9 and Fig. 2, features 76-79). It consisted for the most part of preserved stubs of posts, but as postholes on the shoulder of Hed Mound in the southern half of its western side (Harris 1977: Fig. 2, feature 77). It was not investigated in the northeast corner of the site. On the west, north and east there was a single line of posts, in the south a double line. Tibito Tephra was commonly found around the preserved butts of fence posts, suggesting to Harris (1977: 9) that the fence was still in use at the time of the ashfall. It was difficult for him to assign pits and postholes across the site to their place in the occupation sequence. Harris (1977: 8) treated them as part of Period VII because they could not be stratigraphically shown to belong to Period V or VI. 


\section{Period VIII}

The final phase on Hed Mound before European contact, Period VIII (Harris 1977: 10-11), began sometime after the fall of Tibito Tephra in the AD 1660s, possibly separated by a short time from the end of Period VII. On the other hand, the ditch that was dug for House 5 (Fig. 17.17F) used part of the corresponding ditch of House 4, which might suggest that House 4 remained in use into Period VIII. However, Harris argues (1977: 10) that Period VIII was preceded by the deposition of Layer 2 of the site stratigraphy, a stratum of consistently dark and compact character that buried all the features of Phases V-VII and could have resulted from a period of gardening following Period VII. It was into this new formation that the two major features of Period VIII were dug - the ditch associated with House 5 and a boundary ditch around the top of the hill. These ditches appeared as surface features when the grass was removed prior to excavation (Harris 1977: 11 and Fig. 3; see Fig. 17.17F). They themselves were covered with Layer 1, a humic soil differing mainly from Layer 2 in that it was less compact (1977: 3). The only stone artefacts from the Hed Mound excavations, discussed in Chapter 20, came from Layers 1 and 2.

Though the ditch of House 5 does not completely surround it, it provided a space $6.5 \mathrm{~m}$ northsouth and $8.5 \mathrm{~m}$ east-west for what seems to have been a round or roundish men's house. Because of the gap in the ditch, it is not certain whether three small pits - two probable cooking pits and one hearth-were internal to the house, but they are the only candidates. The house ditch articulated with the ditch dug around the hill, which enclosed an area of some $750 \mathrm{~m}^{2}$ and had an outlet at the southwest corner. Within the compound thus defined, there were hearths and cooking pits. Harris (1977: 21) suggests that Hed Mound may have served as a ceremonial ground at this stage, but admits (1977: 11) that he found no local knowledge of any recent occupation there. It is interesting, however, that workmen found plant remains in small holes at the northwest point of the house (Harris 1977: 10-11, Fig. 3, feature 82) and similar occurrences in the compound (Harris 1977: Fig. 3, features 88-89), which they identified as tanket (Cordyline), whose leaves are used to cover men's buttocks. This would have been appropriate for a ceremonial ground (Strathern 1971: 8, cited by Harris 1977: 21).

\section{An overview of the evidence}

House mounds with accompanying ditches were a feature of the swamp surface at Kuk, mainly clustered along and to the east of Wai's Baret, the major disposal channel of Phases 5 and 6 of the Kuk sequence. Wai's marks the eastern boundary of wetland cultivation in Phase 6, when, it has been suggested, the adoption of the sweet potato as staple allowed the abandonment of the deeper swamp north and east of Wai's Baret at Kuk, as well as much drained and cultivated swamp elsewhere in the upper Wahgi Valley. At Kuk, houses were built to give ready access to the sweet potato gardens across Wai's Baret to the west and to pig-grazing ground that had replaced cultivation to the east. A fence line along the eastern bank of Simon's Baret was evidence of protective measures against pig depredations.

In 1972, Ron Lampert selected a cluster of Phase 6 house mounds at the northern end of block A9g for archaeological investigation, on the basis of which he identified a homestead of four houses for women and pigs and a men's house. All five houses were accompanied by ditches of horseshoe plan, suggesting that they were of what Paul Gorecki subsequently called the 'veranda' type. In the light of his 1977-78 investigations, Gorecki highlighted problems in the interpretation of the form and function of the structures due to the complexity of the ethnographic evidence available for comparison and the limited character of the archaeological evidence. He saw all this as pointing not to a cluster of buildings of a single date, but to the 
relocation and rebuilding of structures by a single family over 'a surprisingly long period of time' (1982: 161), by which he meant, in terms of his Kuk experience, 'probably much longer than 15 years'.

Lampert's excavations of 1973 recovered evidence of two houses of an earlier date beneath the Phase 6 mound cluster of 1972, one of them a veranda house, both allocated to Phase 5 because of the presence of Tibito Tephra in the house ditches. A subsequent review of the dating evidence (Lewis, Denham and Golson 2016) has indicated the ash to be in secondary position.

Veranda houses of Kuk Phase 5 were excavated by Ed Harris in 1977 on top of a small hill, Hed Mound, in the swamp in block A11. There was a sequence of three houses interpreted as being for women and pigs (Mound Periods V-VII) and a smaller structure interpreted as a house for men, with the likelihood of earlier houses now thought of as belonging to Mound Period III, still Kuk Phase 5 but early in it. Harris (1977: 22) considered that the sequence of houses constituting Mound Periods V-VII might mean either their immediate rebuilding at the same location or the repeated use of this over a longer period of time. For Gorecki, the evidence of both the Harris and the Lampert sites pointed to 'the intensive use of house sites at specific locations' (1982: 162) and we might extend this to the evidence of house site distribution as a whole. Gorecki envisaged a stability of economic, social and political life and contrasted it with the unstable situation in the 1970s at Kuk, which he saw as resulting from the regular intake of migrants into the community (see Chapter 23).

This is an interesting interpretation in the light of the fact that the evidence for stability comes from two periods, Phases 5 and 6, the transition between which saw the adoption of a new staple, sweet potato, and the wholesale reorganisation of activities in the swamp. We have limited evidence about the presence and distribution of Phase 5 houses in the swamp, though the appearance of houses then, both in the swamp and on Hed Mound, might be connected with the appearance of raised-bed agriculture in the swamp. Raised-bed cultivation has been argued elsewhere to characterise Phase 5 (see Chapter 15), with a switch from taro to yam as staple, possibly coinciding with the arrival of the pig and perhaps the lesser yam (Dioscorea esculenta) from Austronesian settlements in the lowlands, both of which would have reinforced the new agronomy of raised-bed cultivation. The new agronomy of Phase 5, of course, continued into Phase 6 to become that of the sweet potato.

It can be also argued that the changes in house style that occurred during the contact period in the upper Wahgi Valley were a reflection of the growing importance of pig rearing, which was advantaged by raised-bed cultivation, especially that associated with the sweet potato. Reporting in the early years of contact, Vicedom noted the presence of pigs in all women's and even some family houses and a single entrance shared by pigs and people (Vicedom and Tischner 1943-48 and 1983: Fig. 76). Forty years later, whenever they lived under the same roof, women and pigs had separate quarters and different entrances (Gorecki 1982: 93). Side by side with this change went simplification in other respects, for example, the disappearance of men's houses of subrectangular and veranda type and the lesser importance of veranda houses as a type overall (Gorecki 1982: 87, 97). Gorecki (1982: 93-94) noted a tendency for the houses for women and pigs at Kuk in the 1970s to be longer than simple dwelling houses, though there was great variability in the space provided for pigs, as well as in arrangements for them by way of stalls, such things depending on an individual's 'will, wealth and expectations'. We can expect these developments of the contact period to have had their roots in pre-contact times. 


\section{Acknowledgements}

I am grateful to the three members of the Kuk team, Ron Lampert, Ed Harris and Paul Gorecki, whose work on the archaeological, ethnographic and historical aspects of human settlement at Kuk it has been the aim of this chapter to integrate, for their contributions to a cooperative endeavour at the time of fieldwork and subsequently. I thank Winifred Mumford, then illustrator and cartographer in the ANU Department of Prehistory, whose mapping of the surface indications of drainage channels and house sites exposed in the course of grass cutting and drain digging during the initial fieldwork in 1972, laid the basis for the large-scale plans characteristic of the book as a whole. Finally, I acknowledge the cooperation of Terry Bell, who as an ANU doctoral student in the early 1970s included ovenstones from the Kuk house excavations in his studies of thermoluminescence dating. 
This text is taken from Ten Thousand Years of Cultivation at Kuk Swamp in the Highlands of Papua New Guinea, edited by Jack Golson, Tim Denham, Philip Hughes, Pamela Swadling and John Muke, published 2017 by ANU Press, The Australian National University, Canberra, Australia. 